\title{
Cyclic gallium-68 labeled peptides for specific detection of human angiotensin- converting enzyme 2
}

Matthew F. L. Parker ${ }^{1}$, Joseph Blecha ${ }^{1}$, Oren Rosenberg ${ }^{2}$, Michael Ohliger ${ }^{1,3}$, Robert R.

Flavell $^{1}$, David M. Wilson ${ }^{1 *}$

${ }^{1}$ Department of Radiology and Biomedical Imaging

University of California, San Francisco

San Francisco, CA 94158, USA

${ }^{2}$ Department of Medicine

University of California, San Francisco

San Francisco, CA 94158, USA

${ }^{3}$ Department of Radiology

Zuckerberg San Francisco General Hospital

San Francisco CA 94110, USA

"Correspondence and Reprint Request:

David Wilson, M.D., Ph.D.

Department of Radiology and Biomedical Imaging

University of California, San Francisco

505 Parnassus Ave.

San Francisco, CA 94143

Phone: (415) 353-1668

Fax: (415) 353-8593

david.m.wilson@ucsf.edu

First Author:

Matthew F.L. Parker, Ph.D.

Department of Radiology and Biomedical Imaging

University of California, San Francisco

180 Berry St.

San Francisco, CA 94107

Phone: (415) 353-9401

Fax: (415)

Word count:

Running title: Gallium-68 peptides for ACE2 detection

Acknowledgements: Grant sponsors NIH R01 EB024014; R01 EB025985 
Immediate Open Access: Creative Commons Attribution 4.0 International License (CC BY) allows users to share and adapt with attribution, excluding materials credited to previous publications.

License: https://creativecommons.org/licenses/by/4.0/.

Details: $\underline{\text { https://jnm.snmjournals.org/page/permissions. }}$

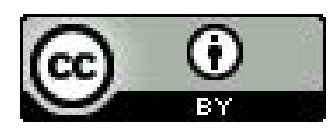

\begin{abstract}
:
In this study, we developed angiotensin converting enzyme II (ACE2)-specific, peptidederived ${ }^{68} \mathrm{Ga}$-labeled radiotracers, motivated by the hypotheses that (1) ACE2 is an important determinant of severe acute respiratory syndrome coronavirus 2 (SARS-CoV2) susceptibility, and (2) that modulation of ACE2 in coronavirus disease 2019 (COVID19) drives severe organ injury.
\end{abstract}

Methods: A series of NOTA-conjugated peptides derived from the known ACE2 inhibitor DX600 were synthesized, with variable linker identity. Since DX600 bears two cystine residues, both linear and cyclic peptides were studied. An ACE2 inhibition assay was used to identify lead compounds, which were labeled with ${ }^{68} \mathrm{Ga}$ to generate peptide radiotracers $\left({ }^{68} \mathrm{Ga}-\mathrm{NOTA}\right.$-PEP). The aminocaproate-derived radiotracer ${ }^{68} \mathrm{Ga}-\mathrm{NOTA}-\mathrm{PEP} 4$ was subsequently studied in a humanized ACE2 (hACE2) transgenic model.

Results: Cyclic DX-600 derived peptides had markedly lower $\mathrm{IC}_{50}$ 's than their linear counterparts. The three cyclic peptides with triglycine, aminocaproate, and polyethylene glycol linkers had calculated $\mathrm{IC}_{50}$ 's similar to, or lower than the parent DX600 molecule. Peptides were readily labeled with ${ }^{68} \mathrm{Ga}$, and the biodistribution of ${ }^{68} \mathrm{Ga}-N O T A-P E P 4$ was determined in a hACE2 transgenic murine cohort. Pharmacologic concentrations of coadministered NOTA-PEP ("blocking") showed significant reduction of ${ }^{68} \mathrm{Ga}-\mathrm{NOTA}$-PEP4 signals in the in the heart, liver, lungs, and small intestine. Ex vivo hACE2 activity in these organs was confirmed as a correlate to in vivo results. 
Conclusions: NOTA-conjugated, cyclic peptides derived from the known ACE2 inhibitor DX600 retain their activity when $\mathrm{N}$-conjugated for ${ }^{68} \mathrm{Ga}$ chelation. In vivo studies in a transgenic hACE2 murine model using the lead tracer ${ }^{68} \mathrm{Ga}-\mathrm{NOTA}-\mathrm{PEP} 4$ showed specific binding in the heart, liver, lungs and intestine - organs known to be affected in SARS-CoV2 infection. These results suggest that ${ }^{68} \mathrm{Ga}-\mathrm{NOTA}$-PEP4 could be used to detect organspecific suppression of ACE2 in SARS-CoV-2 infected murine models and COVID-19 patients.

\section{KEYWORDS:}

COVID-19, ACE2, SARS-CoV-2, ARDS, positron emission tomography 


\section{INTRODUCTION:}

The novel coronavirus severe acute respiratory syndrome coronavirus 2 (SARS-CoV2) has had profound effects on global health, especially in the United States, the country with the largest number of confirmed coronavirus disease 2019 (COVID-19) cases, and associated deaths. Many of these patients progress to Acute Respiratory Distress Syndrome (ARDS), respiratory failure with widespread injury of the lungs. The underlying mechanisms include diffuse alveolar damage, surfactant dysfunction, and immune cell activation(1-3). Of note, many pathologic conditions can cause this convergent picture, including both bacterial and viral infections. These causes of ARDS likely share dysfunction of the renin-angiotensin system, especially loss of angiotensin converting enzyme II (ACE2) function(4-8). ACE2 is a transmembrane protein that functions as angiotensin receptor chaperone. The roles of ACE2, ACE, and angiotensin II are highlighted in Figure $1 \mathrm{~A}$ which describes dual functions of the renin-angiotensin system with opposing effects on cardiovascular biology(9). In this pathway, ACE2 performs an important regulatory role, converting angiotensin II to angiotensin 1,7 which causes vasodilatation and has anti-inflammatory effect, unlike activation of ANGIOTENSIN RECEPTOR which will lead to vasoconstriction, higher blood pressure and inflammation (potentially ARDS)(10-13).

Although several recent papers suggest that other mammalian transmembrane proteins (for example CD147 and CD26) allow SARS-CoV-2 to infect different cell types $(14,15)$, ACE2 is the main point of entry of the virus into host cells (Figure 1B). This process depends on this receptor as well as on its spike (S) protein, with cryo-EM and Xray crystal structures of the complex recently described, as well as characterization of the complex via atomic force microscopy (Figure $1 \mathrm{C})(16-18)$. This protein has 2 subunits- $\mathrm{S} 1$

containing receptor binding domains (RBDs), and S2, which is responsible for membrane fusion. The RBDs can mimic the ACE2 interaction with ANGIOTENSIN RECEPTOR 
(hydrophobic and strong electrostatic interactions, including pi-pi, and cation-pi) and gain entry via strong non-covalent attachment to ACE2 in the ANGIOTENSIN RECEPTOR binding site(19). Three recent cryo-EM studies demonstrated that SARS-CoV-2 spike protein directly binds to ACE2 and that the SARS-CoV-2 spike protein likely recognizes human ACE2 with even higher binding affinity than spike from SARS-CoV(20-22). This binding was suggested to alter virus configuration and expose a cleavage site on S2, resulting in host protease cleavage (mainly by transmembrane protease/serine subfamily member 2 - TMPRSS2), allowing the virus to enter the cell(23). This mechanism was recently supported by a cryo-EM post fusion analysis that showed structural and conformational rearrangements of the S-protein compared to its pre-fusion structure(24).

To investigate SARS-CoV-2 susceptibility, and organ-specific suppression of ACE2 in COVID-19, new ACE2-specific imaging methods would be profoundly helpful. A key hypothesis in COVID-19 is that binding of SARS-CoV-2 to ACE2 results in downregulation of this "beneficial" enzyme, as observed for the original SARS-CoV virus from 2003, which also depends on ACE2 for viral entry. At that time researchers in the Penninger lab found that in preclinical models of acute lung injury, the viral S-protein itself resulted in loss of normal ACE2 function, contributing to severe disease(25). Following this outbreak, several ACE2-specific small molecules and peptides were discovered, motivating our design of active-site targeted, high affinity PET tracers. The reported ACE2-specific ligands, generally characterized by their ACE2 IC 50 's, included the peptide DX600 discovered via phage display(26-31). The DX600 sequence is shown in Figure 1D. In this manuscript, we report development of ACE2-specific PET radiotracers $\left({ }^{68} \mathrm{Ga}-\right.$ NOTA-PEP) derived from this sequence. We anticipate that ACE2-specific PET could help evaluate which systems are most targeted by SARS-CoV-2 infection, the timing of disease, and how ACE2 modulation correlates with ARDS susceptibility and other organ injury. Determining ACE2 expression non-invasively would also help us to better 
understand differential susceptibility to SARS-CoV-2, based on age, gender, and the use of common antihypertensive medications. Recent work has also highlighted the role of ACE2 in a large number of organs beyond the lungs, including the heart, kidneys, and gastrointestinal system(32-37). These other organ systems are affected in COVID-19 with devastating consequences. We therefore believe that the information gleaned from ${ }^{68} \mathrm{Ga}-$ NOTA-PEP4 or some other in vivo ACE2 sensor will potentially be helpful in COVID-19 treatment, either via exogenous ACE2 $(4,38)$ or some other therapy.

\section{MATERIALS AND METHODS:}

Peptides: The DX600-derived peptides studied were obtained from AnaSpec (Fremont, CA) as a custom synthesis, fully characterized by HPLC and mass spectrometry. These peptides were radiolabeled without additional modification. Please see the Supplemental Information for complete documentation provided.

ACE2 inhibition assay: Six DX600-derived peptides, named NOTA-PEP1-6, (cyclic versus non-cyclic, with triglycine, aminocaproate, and polyethylene glycol linkers) were studied using a commercially available ACE2 inhibition assay according to the manufacturer's instructions (SensoLyte 8390 ACE2 Activity Assay Kit *Fluorimetric*, AS72086, AnaSpec, Fremont CA). Each peptide inhibitor was first tested at 4 concentrations. Initial velocities were determined relative to the inhibitor free reaction. Subsequently, $I_{50}$ values were derived from nonlinear fits of saturation curves of a 6-point dilution series of peptide inhibitors.

${ }^{68}$ Ga-peptide synthesis: Full descriptions of radiochemical syntheses, as well as the analytical techniques used, are provided in the Supplemental Information. Unless otherwise noted, all reagents were obtained commercially and used without further purification. ${ }^{68} \mathrm{Ga}$-gallium chloride was generated in the UCSF radiopharmaceutical facility by elution from an ITG germanium-gallium generator. To generator eluted ${ }^{68} \mathrm{Ga}^{-} \mathrm{Cl}_{3}$ in a 
$4 \mathrm{~mL}$ dilute $\mathrm{HCl}$ solution was added the indicated NOTA-PEP precursor $(80 \mu \mathrm{g})$ in $\mathrm{pH} 5$ sodium acetate buffer solution $(160 \mu \mathrm{L})$. The mixture was heated for $15 \mathrm{mins}$ at $90^{\circ} \mathrm{C}$. The reaction was monitored by TLC performed on cellulose filter paper developed in PBS. Free gallium migrates to the solvent front $(\sim 90 \mathrm{~mm})$ and bound gallium remains at the origin ( $20 \mathrm{~mm})$. Crude TLC data were obtained for all ${ }^{68} \mathrm{Ga}-\mathrm{NOTA}$-PEP peptides to determine $\%$ chelation; the lead peptide ${ }^{68} \mathrm{Ga}-N O T A-P E P 4$ was purified using a preconditioned C18 Sep-Pak cartridge, and characterized by analytical HPLC. Stability of ${ }^{68} \mathrm{Ga}-\mathrm{NOTA}-\mathrm{PEP} 4$ was evaluated in phosphate-buffered saline (PBS), mouse serum, and human serum in preparation for animal studies.

$\mu \mathrm{PET} / \mathrm{CT}$ imaging: All animal procedures were approved by the UCSF Institutional Animal Care and Use Committee, and all studies were performed in accordance with UCSF guidelines regarding animal housing, pain management, and euthanasia. Humanized ACE2 recombinant mice (B6.Cg-Tg(K18-ACE2)2PrImn/J, 034860, Jackson Laboratory) were obtained from Jackson Labs, aged 6-10 weeks(39-41). Single time-point imaging: A tail vein catheter was placed in mice under isoflurane anesthesia. Approximately $13 \mathrm{MBq}$ of ${ }^{68} \mathrm{Ga}$-NOTA-PEP4 were injected via the tail vein catheter. The animals were placed on a heating pad to minimize shivering. Mice were allowed to recover, micturate, and at 75 minutes post-injection, placed back under isoflurane anesthesia. At 90 mins post-injection, the animals were transferred to a Siemens Inveon micro PET-CT system (Siemens, Erlangen, Germany), and imaged using a single static 25 min PET acquisition followed by a 10 min micro-CT scan for attenuation correction and anatomical co-registration. No adverse events were observed during or after injection of any compound. Anesthesia was maintained during imaging using isofluorane. Inhibition ("blocking") studies: The protocol was identical to that above but cold NOTA-derived inhibitory cyclic peptide (NOTA-PEP4) $\left(10 \mathrm{mg} / \mathrm{kg}\right.$ dose) was co-administered with ${ }^{68} \mathrm{Ga}-\mathrm{NOTA}-\mathrm{PEP} 4$ in buffered saline. Dynamic imaging: The protocol was similar to above except tail-vein administration of $35013 \mathrm{MBq}$ 
of ${ }^{68} \mathrm{Ga}$-NOTA-PEP4 was performed simultaneously on a cohort of 4 animals in bed positioning for PET imaging. PET imaging data was collected beginning at the moment of injection for 90 minutes followed by 10 -minute CT.

Ex vivo analyses of mice: Upon completion of imaging, mice were sacrificed and biodistribution analysis performed. Gamma counting of harvested tissues was performed using a Hidex Automatic Gamma Counter (Turku, Finland). Organs were also harvested from a separate cohort of mice for an ACE2 activity assay. The tissues were homogenized and aliquots were used for protein concentration using a standard Bradford assay. Additional tissue aliquots were used as the source of ACE2 in a commercially available ACE2 assay (AnaSpec, Fremont, CA). The initial velocities were normalized relative to muscle tissue. Relative activities are reported as the relative initial velocity/g of protein.

Data analysis and statistical considerations: For syntheses, radiochemical yields incorporate decay-correction for ${ }^{68} \mathrm{Ga}\left(\mathrm{t}_{1 / 2}=68 \mathrm{~min}\right)$. All in vivo PET data were viewed using open source Amide software (amide.sourceforge.net). Reported static (single time-point data) reflects gamma counting of harvested tissues. For dynamic data, quantification of uptake was performed by drawing spherical regions of interest $\left(5-8 \mathrm{~mm}^{3}\right)$ over indicated organs on the CT portion of the exam, and expressed as percent injected dose per gram. All statistical analysis was performed using Microsoft Excel. Data were analyzed using an unpaired two-tailed Student's t-test. All graphs are depicted with error bars corresponding to the standard error of the mean.

\section{RESULTS:}

NOTA-conjugated, cyclic peptides targeting the ACE2 active site retain their potency relative to the DX600 parent compound. Based on our hypothesis that potent peptide-derived ACE2 inhibitors, modified with linkers/chelating groups will retain their activity and specificity, several NOTA-modified peptide-derived ACE2 inhibitors derived from the DX600 sequence $(30)\left(K_{i}=2.8 \mathrm{nM}, K_{d}=10.8 \mathrm{nM}\right)$ were synthesized and screened 
for ACE2 inhibition. These were synthesized via Fmoc-protected linkers and N-capping NOTA reagents (Figure 2A,B). The general structure pursued was a NOTA-linker-peptide with three different linkers used, conferring varying degrees of hydrophobicity and hydrogen bonding: triglycine, PEG, or caproic acid. These were synthesized using standard Fmoc solid-phase synthesis(42) (AnaSpec, Fremont CA) with purity and identity confirmed by HPLC and mass spectrometry. Because DX600 contains two cysteine residues, a cyclized set of peptides were also synthesized via disulfide bridge formation(43). When these compounds were compared to the parent DX600 peptide in a commercially available fluorometric ACE2 inhibition assay (AnaSpec), all three cyclic peptides (NOTA-PEP2, NOTA-PEP4, NOTA-PEP6) showed ACE2 inhibition nearly identical to DX600 (Figure 2C,D). In other words, the N-terminal modification caused no loss of inhibitory activity when compared to the parent peptide, and in fact the cyclic peptide NOTA-PEP4 was a slightly better ACE2 inhibitor than DX600. In contrast, the linear derivatives showed much lower activity, which may result from a solution confirmation for which the NOTA interferes with ACE2 active site binding. To further evaluate this loss of potency, we studied ACE2 inhibition using a cyclic NOTA-PEP6 with and without addition of the reducing agent tris(2-carboxyethyl)phosphine (TCEP) which was confirmed to reduce the disulfide bridge in the cyclic peptide (producing the linear NOTA-PEP5) (Figure 2E, Supp. Fig. 1-2). As anticipated, addition of TCEP markedly increased the observed ACE2 $\mathrm{IC}_{50}$.

Efficient radiosyntheses of ${ }^{68}$ Ga-NOTA-PEP peptides. Promising ACE2 inhibition results for NOTA-conjugated cyclic peptides were followed with radiolabeling of peptides with ${ }^{68} \mathrm{Ga}$ (44) (Supp. Fig. 3). Crude radiochemical yields of the desired ${ }^{68} \mathrm{Ga}$-peptide chelate were $>80 \%$ in all cases by TLC. The majority of synthetic efforts focused on optimizing the radiosynthesis of the lead inhibitor ${ }^{68} \mathrm{Ga}-\mathrm{NOTA}-\mathrm{PEP} 4 .{ }^{68} \mathrm{Ga}-\mathrm{NOTA}-\mathrm{PEP} 4$ was synthesized in 30 mins from generator eluted ${ }^{68} \mathrm{Ga}_{-} \mathrm{Cl}_{3}$ in a $4 \mathrm{~mL}$ dilute $\mathrm{HCl}$ solution. 
The precursor $(80 \mu \mathrm{g})$ was added as a pH 5 acetate buffer solution $(160 \mu \mathrm{L})$ and heated for 15 mins at $90^{\circ} \mathrm{C}$. The crude mixture was purified via a preconditioned C18 Sep-Pak cartridge resulting in ${ }^{68} \mathrm{Ga}-\mathrm{NOTA}-\mathrm{PEP} 4$ with $>99 \%$ radiochemical purity as determined by Radio TLC (Figure 3A) and HPLC (Supp. Fig. 4). The decay-adjusted radiochemical yield of ${ }^{68} \mathrm{Ga}$-NOTA-PEP4 was $63.2 \pm 6.4 \%(\mathrm{~N}=8)$ with an approximate molar activity greater than or equal to $15.6 \mathrm{GBq} / \mu \mathrm{mol}$. In preparation for animal studies, stability of ${ }^{68} \mathrm{Ga}-$ NOTA-PEP4 was confirmed in PBS, mouse serum, and human serum (Supp. Fig 5).

${ }^{68}$ Ga-NOTA-PEP4 signals in the lungs, heart, small intestine and liver of hACE2 transgenic mice are attenuated with co-administration of inhibitory cyclic peptide. Having developed a radiosynthesis of ${ }^{68} \mathrm{Ga}-\mathrm{NOTA}$-PEP4, we sought to further validate the tracer in a transgenic, humanized ACE2 (hACE2) murine model. The K18-hACE2 transgenic mice express human ACE2 under the control of the human keratin 18 promoter, which directs expression to epithelia, including airway epithelial cells where infections typically begin(39). Preliminary studies available from the Jackson Laboratory website, and recently published studies(45) have shown that K18-hACE2 transgenic mice develop dose-dependent disease phenotypes when infected intranasally with SARS-CoV-2 with high doses resulting in ARDS/death analogous to that observed in some COVID-19 patients. Male $\operatorname{Tg}(\mathrm{K} 18-\mathrm{ACE} 2) 2 \mathrm{Pr} / \mathrm{mn} / \mathrm{J}$ hemizygous mice $(\mathrm{N}=4$, Jackson Lab) were initially injected with $13.0 \mathrm{MBq}$ of ${ }^{68} \mathrm{Ga}-\mathrm{NOTA}-\mathrm{PEP} 4$ and dynamic imaging was performed to identify optimum single time-point imaging. Region of interest (ROI) analysis of dynamic data was focused on organs known to be affected in SARS-CoV-2 (Figure 3B, Supp. Fig. 6). ROI analysis of the images demonstrated prompt clearance from the blood pool with accumulation in the kidneys, as expected for a small peptide tracer.

Next, we performed an imaging and biodistribution study, to show that ${ }^{68} \mathrm{Ga}-\mathrm{NOTA}$ PEP4 demonstrates specific uptake in tissues with increased expression of ACE2 (Figure 
4). In order to demonstrate specificity of uptake, blocking with excess cyclic NOTA-PEP inhibitory peptide was employed. With blocking, significant reductions in cyclic ${ }^{68} \mathrm{Ga}-$ NOTA-PEP4 were seen in the heart $(2.5$-fold, $p=0.0203)$, lung $(2.5$-fold, $p<0.0001)$, liver (2.8-fold, $p<0.0001)$ and small intestine $(2.4$-fold, $p=0.0002)$. ACE2 activity in these organs was subsequently confirmed via harvested organs in a separate hACE2 cohort (N $=3$, Supp. Fig. 7). Taken together, these data demonstrate that ${ }^{68} \mathrm{Ga}-N O T A-P E P 4$ can specifically bind to tissues with high ACE2 expression.

\section{DISCUSSION:}

The novel coronavirus disease (COVID-19) has spread rapidly throughout the world with the highest number of confirmed cases and deaths in the United States. Both biochemical studies and published cryo-EM structures have shown that the spike protein (S-protein) of severe acute respiratory syndrome coronavirus 2 (SARS-CoV-2) predominantly uses human angiotensin-converting enzyme 2 (ACE2) for viral entry, resulting in suppression of this enzyme as seen in SARS-CoV(25,46). Additional recent publications have highlighted the possibility that the lower ACE2 activity seen with SARSCoV-2 infection may be responsible for the physiologic effects incurred, analogous to what was seen with the original SARS-CoV(25). These observations support recombinant ACE2-derived therapies as a way to treat COVID-19, via two mechanisms: (1) by replenishing "protective" ACE2 function and (2) by serving as a "decoy" receptor for the virus. These therapeutic effects, the differential susceptibility of individuals (based on age, co-morbidities) to COVID-19, and the organ-specific effects of SARS-CoV-2 are all potentially addressed by an ACE2-specific imaging method. We therefore sought a PET tracer derived from known inhibitor structures, via modification of the known ACE2 inhibitory peptide DX600 with ${ }^{68} \mathrm{Ga}$.

Inhibitor-derived structures modified for PET do not necessarily recapitulate the potency of their parent compounds, so our first efforts focused on the "cold" NOTA- 
conjugated DX600 derived peptides, derived from triglycine, caproic acid, and PEG linkers. Gratifyingly, the DX600-derived cyclic peptides studied all showed ACE2 activity similar to the parent peptide. In contrast, the linear versions were relatively inactive, which may reflect conformational effects. Of note, the calculated $\mathrm{IC}_{50}$ of $\mathrm{DX} 600$ (standard included in AnaSpec assay kit) was $>1$ order of magnitude higher than the $\mathrm{K}_{\mathrm{i}}$ reported by Huang et al.(30), likely reflecting numerous experimental differences (enzyme concentration and activity, etc.). We therefore considered the $\mathrm{IC}_{50}$ of the NOTA-derived peptides relative to that of DX600 to be the most important determinant of successful PET probe development. Indeed, our lead cyclic peptide NOTA-PEP4 had an $\mathrm{IC}_{50}$ lower than that of the DX600 parent, motivating the radiolabeling of NOTA-PEP4 for subsequent imaging studies.

A high-yield and efficient synthesis of ${ }^{68} \mathrm{Ga}-\mathrm{NOTA}-\mathrm{PEP} 4$ was developed with the tracer applied to a hACE2 transgenic model. Our studies co-injecting a pharmacologic concentration of NOTA-PEP inhibitor with ${ }^{68} \mathrm{Ga}-\mathrm{NOTA}-\mathrm{PEP} 4$ showed significant attenuation of PET signals in the lungs, liver, heart, and small intestine- suggesting that these signals were related to ACE2 expression. Consistent with this observation, ex vivo tissue-specific ACE2 activity was observed in these organs, which are affected in COVID19(47,48). Modulation of ${ }^{68} \mathrm{Ga}-\mathrm{NOTA}$-PEP4 using an ACE2 inhibitor also suggests that changes in ACE2 expression can be detected non-invasively. Additionally, ex vivo tissue analysis showed metabolically activity ACE2 expression in the kidneys despite the absence of strong "blocking." The tissue accumulation of ${ }^{68} \mathrm{Ga}-N O T A-P E P 4$ in the kidneys suggests a dominant renal excretion pathway, complicating our ability to detect hACE2 in this tissue(49). In other words, high background signal due to the normal excretion pathway of ${ }^{68} \mathrm{Ga}-\mathrm{NOTA}-\mathrm{PEP} 4$ may represent a limitation of this method to detect ACE2 activity in the kidney. In the future, hACE2 expression-specific ${ }^{68} \mathrm{Ga}-\mathrm{NOTA}-\mathrm{PEP} 4$ signals versus background excretion needs to be further clarified, perhaps using koACE2 
animals(50) in addition to the inhibitory studies described in this manuscript.

The in vivo studies performed also reflect a limitation of most academic centers in the United States; specifically, few facilities have a biosafety level 3 (BSL-3) compatible $\mu$ PET-CT imaging system. Future molecular imaging of live SARS-CoV-2 (a BSL-3 organism) and its host effects will therefore require collaborative work with those few centers able to accommodate these studies(51). Given the history of ACE2 with respect to SARS-CoV (the 2003 SARS coronavirus) and ARDS, we expect that new ACE2-specific PET tools will be relevant beyond the current pandemic. We are partially motivated by data indicating that zoonotic infections especially coronavirus-related are on the rise(52). The incidence of emerging and re-emerging zoonotic disease is increasing in many parts of the world, with animal viruses able to cross species barriers to infect humans; it appears likely that ACE2 will be relevant in future pandemics. Better understanding ACE2 suppression, and differential susceptibility to SARS-COV-2 will help us better treat COVID19 and other diseases for which ACE2 plays a critical role.

\section{CONCLUSIONS:}

Our study shows that the ACE2 active site-targeted inhibitor DX600 can be modified for PET via NOTA/linker modification, without loss of activity for cyclized peptides. All peptides studied are readily radiolabeled with ${ }^{68} \mathrm{Ga}$. In a humanized ACE2 transgenic murine model, the lead radiotracer ${ }^{68} \mathrm{Ga}-\mathrm{NOTA}$-PEP4 shows dominant excretion from the kidneys, with attenuated uptake in the lungs, liver, heart, and small intestine when an ACE2 inhibitor is co-administered. These results suggest that modulation of ACE2, as occurring in SARS-CoV-2 infection, can be detected using ${ }^{68} \mathrm{Ga}-\mathrm{NOTA}-\mathrm{PEP} 4$ or related approaches. Future studies include application of ${ }^{68}$ Ga-NOTA-PEP4 to SARS-CoV-2 infected hACE2 mice. 


\section{AUTHOR CONTRIBUTIONS:}

DMW proposed and supervised the overall project. MP, JB, RF performed or supported the radiochemistry. MP performed $\mu$ PET-CT imaging studies and subsequent data analysis. MP performed ex vivo analysis. DMW, MP, JB, RF, OR, MO wrote and edited the paper.

\section{CORRESPONDING AUTHOR:}

*E-mail: david.m.wilson@ucsf.edu

\section{NOTES:}

The authors declare no competing financial or other interests.

\section{ACKNOWLEDGEMENTS:}

Grant sponsors NIH R01 EB024014; R01 EB025985; UCSF Resource Allocation Program. The authors would also like to thank Prof. Sanjay Jain and Alvaro Ordonez (Johns Hopkins University) for helpful conversations.

\section{SUPPLEMENTAL INFORMATION:}

Please see the supplemental information for detailed information regarding synthesis, and several imaging studies not reported in the main text. 


\section{KEY POINTS:}

Question: Can ACE2, the main receptor for SARS-CoV-2, be detected using positron emission tomography? Pertinent findings: NOTA-conjugated, cyclic peptides derived from the known ACE2 inhibitor DX600 retain their activity when $\mathrm{N}$-conjugated for ${ }^{68} \mathrm{Ga}$ chelation. In vivo studies in a transgenic hACE2 murine model using the lead tracer ${ }^{68} \mathrm{Ga}-$ NOTA-PEP4 showed specific binding in the heart, liver, lungs and intestine - organs known to be affected in SARS-CoV-2 infection. Implications for patient care: The spatiotemporal distribution of ACE2 suppression in COVID-19 will be helpful both in understanding the disease and in future treatments. Specifically, the loss of normal ACE2 activity is implicated in organ dysfunction (particularly lung dysfunction), a deficit that may be addressed by recombinant ACE2 administration or some other therapy. 


\section{REFERENCES:}

1. Matthay MA, Zemans RL, Zimmerman GA, et al. Acute respiratory distress syndrome. Nat Rev Dis Primers. 2019;5:18.

2. Thompson BT, Chambers RC, Liu KD. Acute respiratory distress syndrome. $N$ Engl J Med. 2017;377:1904-1905.

3. Proudfoot AG, McAuley DF, Griffiths MJD, et al. Human models of acute lung injury. Dis Model Mech. 2011;4:145-153.

4. Zhang $\mathrm{H}$, Baker $\mathrm{A}$. Recombinant human ACE2: acing out angiotensin II in ARDS therapy. Crit Care. 2017;21:305.

5. Wösten-van Asperen RM, Lutter R, Specht PA, et al. Acute respiratory distress syndrome leads to reduced ratio of ACE/ACE2 activities and is prevented by angiotensin-(1-7) or an angiotensin II receptor antagonist. J Pathol. 2011;225:618627.

6. Annoni F, Orbegozo D, Rahmania L, et al. Angiotensin-converting enzymes in acute respiratory distress syndrome. Intensive Care Med. 2019;45:1159-1160.

7. $\quad \mathrm{Li} \mathrm{Y,} \mathrm{Zeng} \mathrm{Z,} \mathrm{Cao} \mathrm{Y,} \mathrm{et} \mathrm{al.} \mathrm{Angiotensin-converting} \mathrm{enzyme} 2$ prevents lipopolysaccharide-induced rat acute lung injury via suppressing the ERK1/2 and NF-kB signaling pathways. Sci Rep. 2016;6:27911.

8. Kuba K, Imai Y, Rao S, et al. Lessons from SARS: control of acute lung failure by the SARS receptor ACE2. J Mol Med. 2006;84:814-820.

9. Marian AJ. The discovery of the ACE2 gene. Circ Res. 2013;112:1307-1309.

10. Zhang H, Penninger JM, Li Y, Zet al. Angiotensin-converting enzyme 2 (ACE2) as a SARS-CoV-2 receptor: molecular mechanisms and potential therapeutic target. Intensive Care Med. 2020;46:586-590.

11. Peiró C, Moncada S. Substituting Angiotensin-(1-7) to Prevent Lung Damage in SARS-CoV-2 Infection? Circulation. 2020;141:1665-1666.

12. Imai $\mathrm{Y}$, Kuba K, Rao S, et al. Angiotensin-converting enzyme 2 protects from severe acute lung failure. Nature. 2005;436:112-116.

13. Imai Y, Kuba K, Neely GG, et al. Identification of oxidative stress and Toll-like receptor 4 signaling as a key pathway of acute lung injury. Cell. 2008;133:235249.

14. Radzikowska U, Ding M, Tan G, et al. Distribution of ACE2, CD147, CD26, and other SARS-CoV-2 associated molecules in tissues and immune cells in health and in asthma, COPD, obesity, hypertension, and COVID-19 risk factors. Allergy. 2020;75:2829-2845.

15. Wang K, Chen W, Zhou Y-S, et al. SARS-CoV-2 invades host cells via a novel route: CD147-spike protein. BioRxiv. 2020;

16. Lan J, Ge J, Yu J, et al. Structure of the SARS-CoV-2 spike receptor-binding domain bound to the ACE2 receptor. Nature. 2020;581:215-220.

17. Yan R, Zhang Y, Li Y, et al. Structural basis for the recognition of SARS-CoV-2 by full-length human ACE2. Science (80-. ). 2020;367:1444-8.

18. Yang J, Petitjean SJL, Koehler M, et al. Molecular interaction and inhibition of SARS-CoV-2 binding to the ACE2 receptor. Nat Commun. 2020;11:4541.

19. Chowdhury R, Maranas CD. Biophysical characterization of the SARS-CoV2 spike protein binding with the ACE2 receptor explains increased COVID-19 pathogenesis. BioRxiv. 2020;

20. Walls AC, Park Y-J, Tortorici MA, et al. Structure, Function, and Antigenicity of the SARS-CoV-2 Spike Glycoprotein. Cell. 2020;181:281-292.e6.

21. Wan Y, Shang J, Graham R, et al. Receptor Recognition by the Novel Coronavirus from Wuhan: an Analysis Based on Decade-Long Structural Studies of SARS 
Coronavirus. J Virol. 2020;94(7).

22. Wrapp D, Wang N, Corbett KS, et al. Cryo-EM structure of the 2019-nCoV spike in the prefusion conformation. Science (80-. ). 2020;367:1260-1263.

23. Heurich A, Hofmann-Winkler H, Gierer S, et al. TMPRSS2 and ADAM17 cleave ACE2 differentially and only proteolysis by TMPRSS2 augments entry driven by the severe acute respiratory syndrome coronavirus spike protein. $J$ Virol. 2014;88:1293-1307.

24. Fan X, Cao D, Kong L, et al. Cryo-EM analysis of the post-fusion structure of the SARS-CoV spike glycoprotein. Nat Commun. 2020;11:3618.

25. Kuba K, Imai Y, Rao S, et al. A crucial role of angiotensin converting enzyme 2 (ACE2) in SARS coronavirus-induced lung injury. Nat Med. 2005;11:875-879.

26. Dales NA, Gould AE, Brown JA, et al. Substrate-based design of the first class of angiotensin-converting enzyme-related carboxypeptidase (ACE2) inhibitors. J Am Chem Soc. 2002;124:11852-11853.

27. Mores A, Matziari M, Beau F, et al. Development of potent and selective phosphinic peptide inhibitors of angiotensin-converting enzyme 2. J Med Chem. 2008;51:2216-2226.

28. Huentelman MJ, Zubcevic J, Hernández Prada JA, et al. Structure-based discovery of a novel angiotensin-converting enzyme 2 inhibitor. Hypertension. 2004;44:903-906.

29. Deaton DN, Graham KP, Gross JW, et al. Thiol-based angiotensin-converting enzyme 2 inhibitors: P1' modifications for the exploration of the S1' subsite. Bioorg Med Chem Lett. 2008;18:1681-1687.

30. Huang L, Sexton DJ, Skogerson K, et al. Novel peptide inhibitors of angiotensinconverting enzyme 2. J Biol Chem. 2003; 278:15532-15540.

31. Han DP, Penn-Nicholson A, Cho MW. Identification of critical determinants on ACE2 for SARS-CoV entry and development of a potent entry inhibitor. Virology. 2006;350:15-25.

32. Crackower MA, Sarao R, Oudit GY, et al. Angiotensin-converting enzyme 2 is an essential regulator of heart function. Nature. 2002;417:822-828.

33. Danilczyk U, Penninger JM. Angiotensin-converting enzyme II in the heart and the kidney. Circ Res. 2006;98:463-471.

34. Ding $\mathrm{Y}, \mathrm{He} \mathrm{L}$, Zhang $\mathrm{Q}$, et al. Organ distribution of severe acute respiratory syndrome (SARS) associated coronavirus (SARS-CoV) in SARS patients: implications for pathogenesis and virus transmission pathways. J Pathol 2004;203:622-630.

35. Gu J, Gong E, Zhang B, et al. Multiple organ infection and the pathogenesis of SARS. J Exp Med. 2005;202:415-424.

36. Hamming I, Timens W, Bulthuis MLC, et al. Tissue distribution of ACE2 protein, the functional receptor for SARS coronavirus. A first step in understanding SARS pathogenesis. J Pathol. 2004;203:631-637.

37. Deng $Q$, Hu B, Zhang $Y$, et al. Suspected myocardial injury in patients with COVID-19: Evidence from front-line clinical observation in Wuhan, China. Int $J$ Cardiol. 2020;311:116-121.

38. Oudit GY, Penninger JM. Recombinant human angiotensin-converting enzyme 2 as a new renin-angiotensin system peptidase for heart failure therapy. Curr Heart Fail. Rep. 2011;8:176-183.

39. McCray PB, Pewe L, Wohlford-Lenane C, et al. Lethal infection of K18-hACE2 mice infected with severe acute respiratory syndrome coronavirus. J Virol. 2007;81:813-821.

40. Zheng J, Roy Wong L-Y, Li K, et al. K18-hACE2 Mice for Studies of COVID-19 Treatments and Pathogenesis Including Anosmia. BioRxiv. 2020; 
41. Oladunni FS, Park J-G, Pino PA, et al. Lethality of SARS-CoV-2 infection in K18 human angiotensin-converting enzyme 2 transgenic mice. Nat Commun. 2020;11:6122.

42. Behrendt R, White $\mathrm{P}$, Offer J. Advances in Fmoc solid-phase peptide synthesis. $J$ Pept Sci. 2016;22:4-27.

43. Tapeinou A, Matsoukas M-T, Simal C, et al. Review cyclic peptides on a merry-goround; towards drug design. Biopolymers. 2015;104:453-461.

44. Burke BP, Clemente GS, Archibald SJ. Recent advances in chelator design and labelling methodology for (68) Ga radiopharmaceuticals. J Labelled Comp. Radiopharm. 2014;57:239-243.

45. Bao L, Deng W, Huang B, et al. The pathogenicity of SARS-CoV-2 in hACE2 transgenic mice. Nature. 2020;583:830-833.

46. Chung MK, Karnik S, Saef J, et al. SARS-CoV-2 and ACE2: The biology and clinical data settling the ARB and ACEI controversy. EBioMedicine. 2020;58:102907.

47. Gupta A, Madhavan MV, Sehgal K, et al. Extrapulmonary manifestations of COVID-19. Nat Med. 2020;26:1017-1032.

48. Ackermann M, Verleden SE, Kuehnel M, et al. Pulmonary Vascular Endothelialitis, Thrombosis, and Angiogenesis in Covid-19. N Engl J Med. 2020;383:120-128.

49. Koitka A, Cooper ME, Thomas MC, et al. Angiotensin converting enzyme 2 in the kidney. Clin Exp Pharmacol Physiol. 2008;35:420-425.

50. Jia H, Yue X, Lazartigues E. ACE2 mouse models: a toolbox for cardiovascular and pulmonary research. Nat Commun. 2020;11:5165.

51. Ordonez AA, Wang H, Magombedze $\mathrm{G}$, et al. Dynamic imaging in patients with tuberculosis reveals heterogeneous drug exposures in pulmonary lesions. Nat Med. 2020;26:529-534.

52. Cascio A, Bosilkovski M, Rodriguez-Morales AJ, et al. The socio-ecology of zoonotic infections. Clin Microbiol Infect. 2011;17:336-342. 


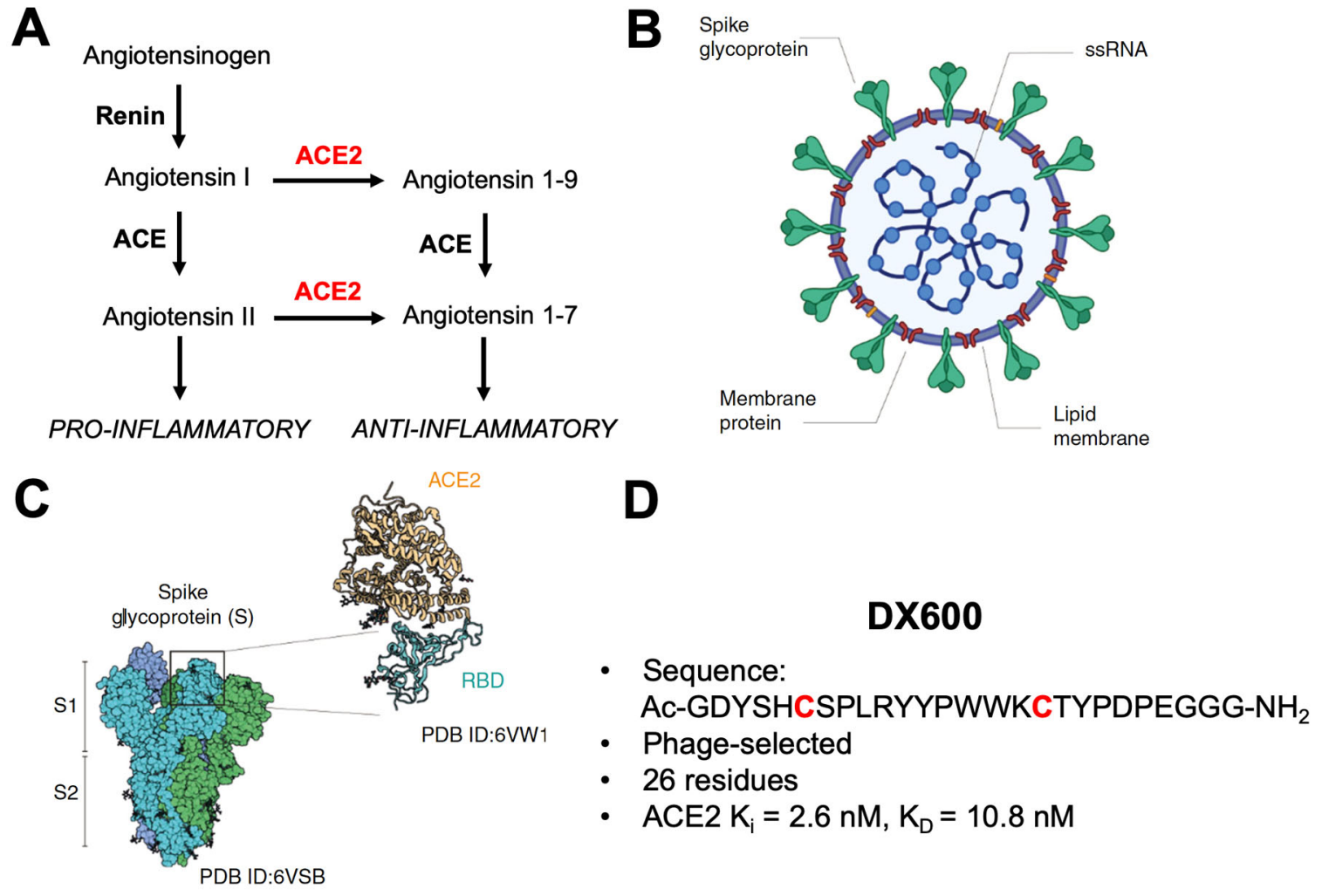

Figure 1. Role of ACE2 in hypertension and SARS-CoV-2 infection. (a) The reninangiotensin system. The role of ACE2 highlighted on the right; ACE2 generally counters the "vasoconstrictive" pathway initiated by the formation of angiotensin II. (b) Simplified structure of the SARS-CoV-2 virus indicating the spike glycoprotein that interacts with ACE2 and other host proteins. (c) Structural (cryoEM, X-ray crystallography) and atomic force microscopy have elucidated the interaction between the spike protein $\mathrm{S} 1$ subunit and ACE2. Of note S1 binds to an ACE2 site remote to its active site, which is targeted by the inhibitory peptides described in this manuscript. Images adapted from Yang et al. 2020 (18); source article is licensed under a Creative Commons Attribution 4.0 International License. (d) Characteristics of the 26-residue DX600 peptide. This peptide contains two cysteine residues, used for cyclization via disulfide bridge formation. DX600 was discovered via phage display and shown by Huang et al. (30) to be a potent ACE2 inhibitor, a calculated $K_{D}$ of $10.8 \mathrm{nM}$, and specificity for ACE2 versus angiotensin converting enzyme (ACE) and carboxypeptidase A (CPA). 


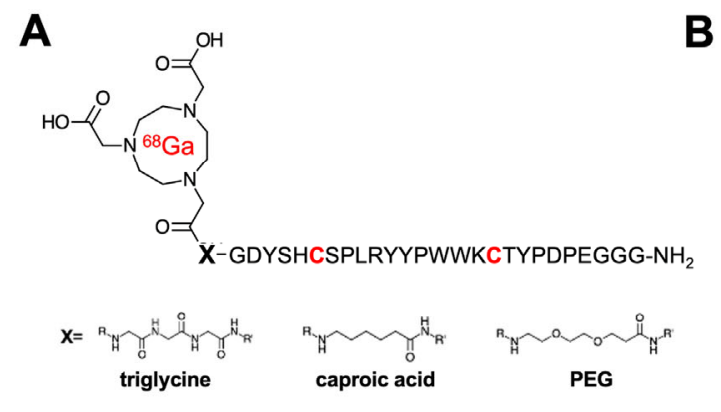

\begin{tabular}{|c|c|c|c|}
\hline Peptide & {$\left[{ }^{68} \mathrm{Ga}\right]$ structure } & Linker & Cyclized \\
\hline PEP1 & ${ }^{68} \mathrm{Ga}-N O T A-P E P 1$ & triglycine & No \\
\hline PEP2 & ${ }^{68} \mathrm{Ga}-\mathrm{NOTA}-\mathrm{PEP} 2$ & triglycine & Yes \\
\hline PEP3 & ${ }^{68} \mathrm{Ga}-\mathrm{NOTA}-\mathrm{PEP} 3$ & caproic acid & No \\
\hline PEP4 & ${ }^{68} \mathrm{Ga}-N O T A-P E P 4$ & caproic acid & Yes \\
\hline PEP5 & ${ }^{68} \mathrm{Ga}-\mathrm{NOTA-PEP5}$ & PEG & No \\
\hline PEP6 & ${ }^{68} \mathrm{Ga}-N O T A-P E P 6$ & PEG & Yes \\
\hline
\end{tabular}

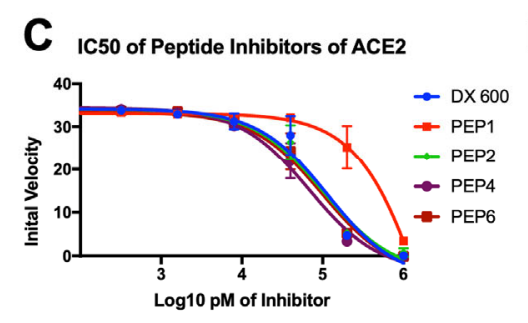

\begin{tabular}{|c|c|c|}
\hline $\mathbf{D}$ & Peptide & $\mathbf{I C}_{\mathbf{5 0}}$ \\
\hline DX600 & $113.6 \mathrm{nM}$ \\
\hline PEP1 & $2.4 \mu \mathrm{M}$ \\
\hline PEP2 & $100.7 \mathrm{nM}$ \\
\hline PEP4 & $67.6 \mathrm{nM}$ \\
\hline PEP6 & $97.7 \mathrm{nM}$ \\
\hline
\end{tabular}

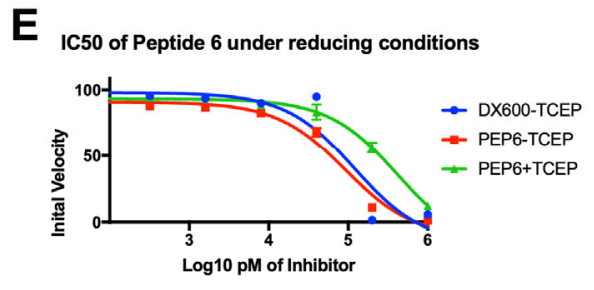

Figure 2. Discovery of DX600-derived, NOTA-conjugated cyclic peptide inhibitors of ACE2 from a small library. (a) General ${ }^{68} \mathrm{Ga}$ - peptide structure pursued. Peptides studied had an N-terminal NOTA chelating group, triglycine/caproic acid/PEG linkers with varying degrees of hydrophobicity and hydrogen-bonding, and +/- cyclization via the cysteine residues highlighted in red. (b) Identity of 6 NOTA-conjugated peptides studied. (c) Cyclic peptides demonstrated greater potency versus their linear counterparts, as highlighted by the initial ACE2 velocities seen with increasing inhibitor concentrations. All cyclic peptides (NOTA-PEP2, NOTA-PEP4, NOTA-PEP6) had similar profiles to the parent peptide DX600, in contrast to linear peptide NOTA-PEP1. (d) ACE2 IC 50 's calculated from these data. Of note these $1 \mathrm{C}_{50}$ 's are significantly higher than the $\mathrm{K}_{i}$ 's reported by Huang et al. for DX600, likely reflecting differences in the assays used. However, most importantly NOTA-conjugated cyclic derivatives had no loss of potency relative to the $D X 600$ parent. (e) The effects of cyclization were highlighted in a separate ACE2 assay using TCEP to reduce the disulfide bridges in NOTA-PEP6. 

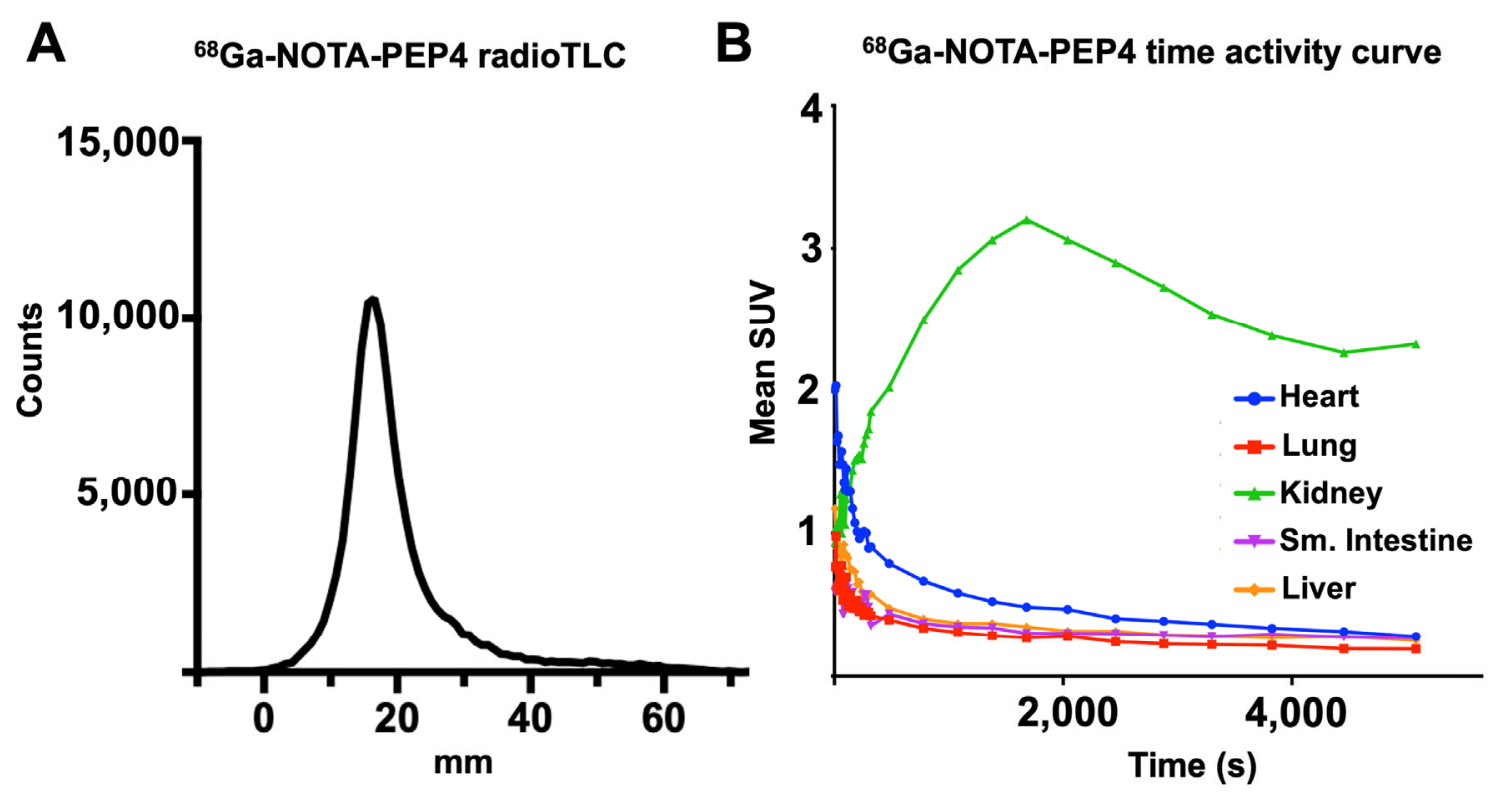

Figure 3. Radiosynthesis and in vivo dynamic characterization of ${ }^{68} \mathrm{Ga}-\mathrm{NOTA}-\mathrm{PEP} 4$. Based on $\mathrm{IC}_{50}$ data, NOTA-PEP4 was chosen for subsequent radiolabeling with ${ }^{68} \mathrm{Ga}$. (a) Our optimized radiosynthesis yielded the desired ${ }^{68} \mathrm{Ga}-\mathrm{NOTA}-\mathrm{PEP} 4$ in greater than $95 \%$ radiochemical purity. (b) Dynamic $\mu \mathrm{PET}-\mathrm{CT}$ in hACE2 transgenic mice was used to generate an organ-specific time-activity curve, identifying later time points as generating stable ${ }^{68} \mathrm{Ga}$ - signals. 


\section{${ }^{68} \mathrm{Ga}-\mathrm{NOTA}$-PEP4 biodistribution in hACE2 mice +/- ACE2 inhibitor}

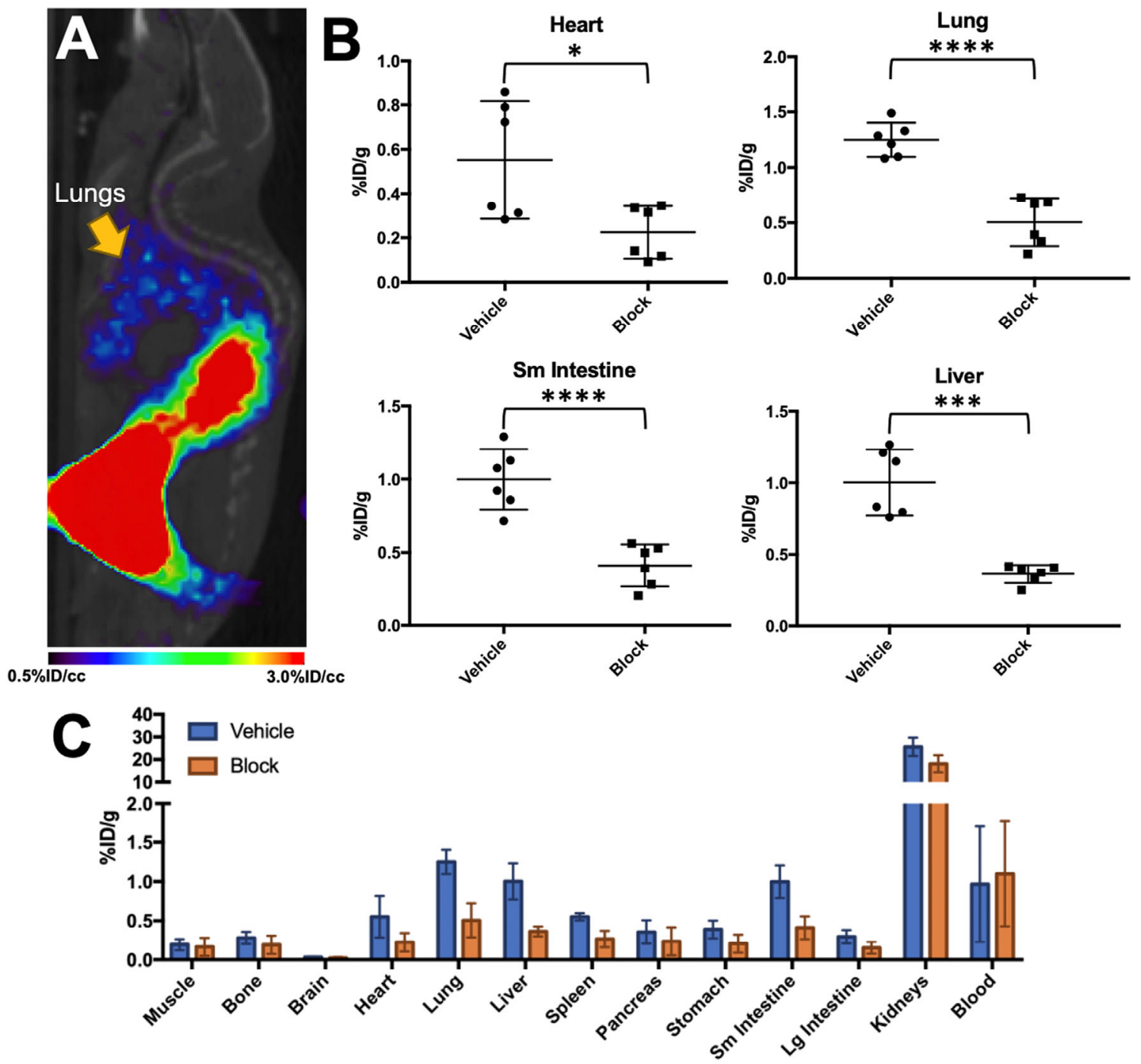

Figure 4. In vivo biodistribution studies of ${ }^{68} \mathrm{Ga}-\mathrm{NOTA}-\mathrm{PEP} 4$ in hACE2 transgenic mice, demonstrating modulation of signals with a pharmacologic dose of ACE2 inhibitor. (a) $\mu \mathrm{PET}-\mathrm{CT}$ image from a static acquisition highlighting the signal corresponding to the lungs, which are of exceptional interest in SARS-CoV-2 infection. (b) Biodistribution of ${ }^{68} \mathrm{Ga}-N O T A-P E P 4$ in the heart, lungs, liver and small intestine, with and without the presence of an ACE2 inhibitor. Significant blocking (unpaired Student's t-test) of ${ }^{68} \mathrm{Ga}$-NOTA-PEP4 was seen in the heart, lungs, liver, and small intestine, organs implicated in COVID-19. (c) Full biodistribution studies. The highest signals were observed in the kidneys, but the observed \%ID/g was not significantly lower in the presence of ACE2 inhibitor. Therefore renal signals are felt to represent the primary route of excretion. 


\section{Graphical Abstract}
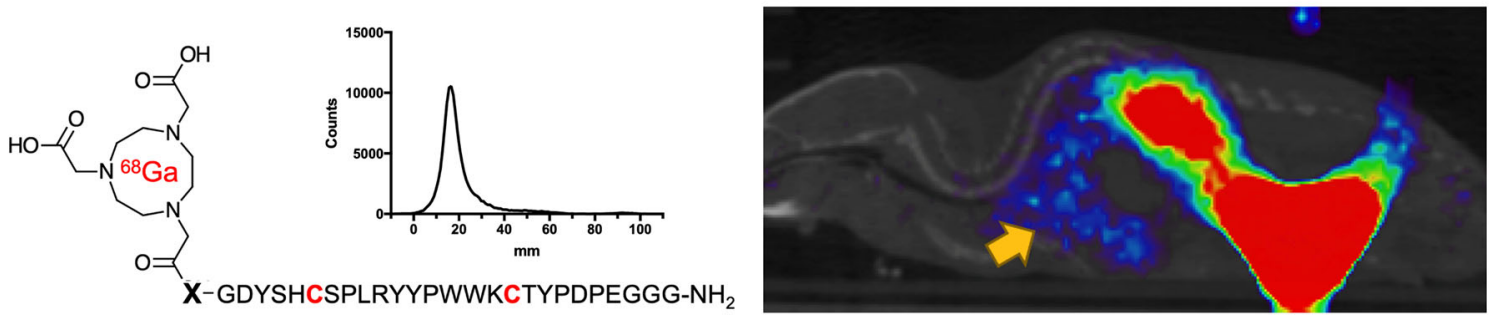
Matthew F. L. Parker ${ }^{1}$, Joseph Blecha ${ }^{1}$, Oren Rosenberg ${ }^{2}$, Michael Ohliger ${ }^{1,3}$, Robert R. Flavell ${ }^{1}$, David M. Wilson $^{1 *}$

${ }^{1}$ Department of Radiology and Biomedical Imaging

University of California, San Francisco

San Francisco, CA 94158, USA

${ }^{2}$ Department of Medicine

University of California, San Francisco

San Francisco, CA 94158, USA

${ }^{3}$ Department of Radiology

Zuckerberg San Francisco General Hospital

San Francisco CA 94110, USA

\section{TABLE OF CONTENTS}

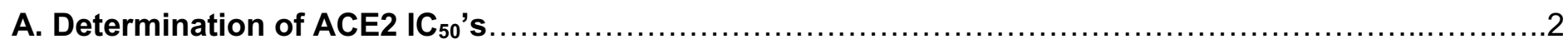

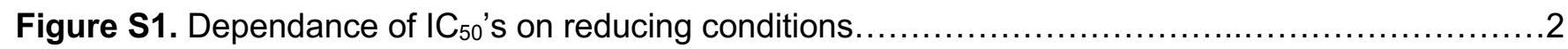

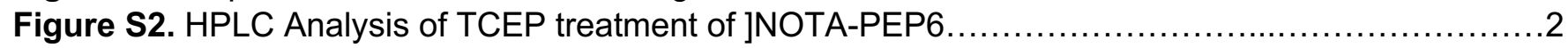

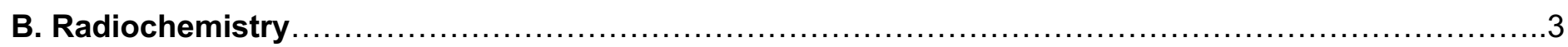

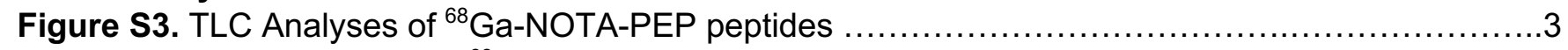

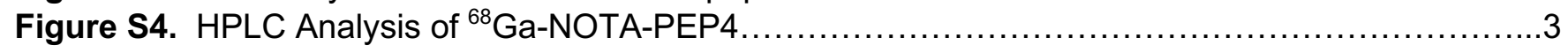

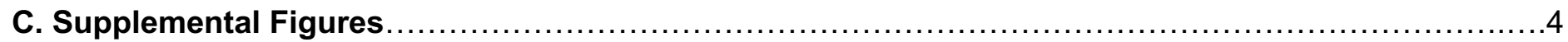

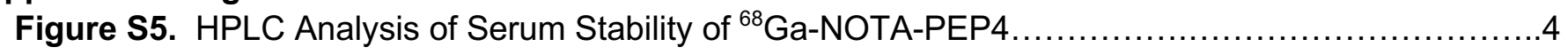

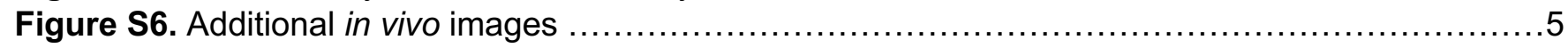

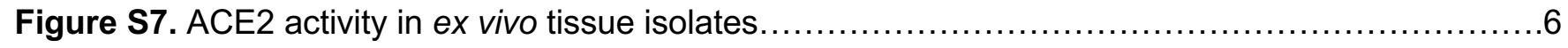

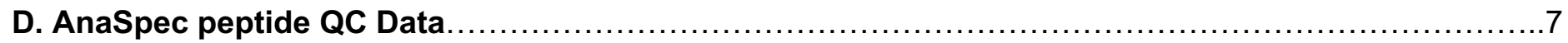




\section{A. Determination of ACE2 IC 50 's:}

\begin{tabular}{|c|c|}
\hline PEPTIDE & IC50 \\
\hline DX600 & $118.2 \mathrm{nM}$ \\
\hline 6-TCEP & $90.93 \mathrm{nM}$ \\
\hline 6+TCEP & $412.5 \mathrm{nM}$ \\
\hline
\end{tabular}

Supp. Fig. 1: ACE2 IC 50 's for NOTA-PEP6 when TCEP is used for disulfide bridge reduction (conversion of cyclic to linear peptide). An approximately 5 -fold higher calculated $I_{50}$ was observed in the presence of TCEP.

\section{TCEP Treatment}

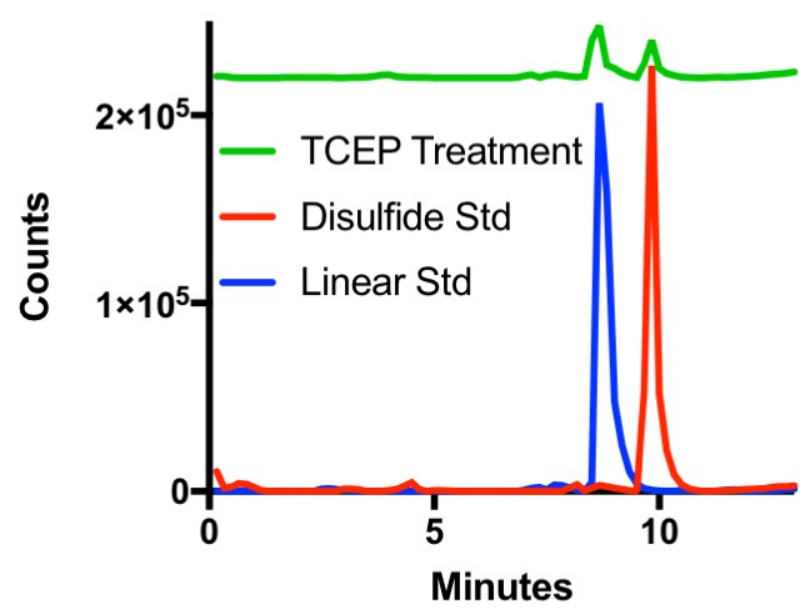

Supp. Fig. 2: HPLC (C18; isocratic $70 \% \mathrm{MeCN}_{\text {in }} \mathrm{H}_{2} 0$ ) confirmation of reduction of the disulfide bridge in NOTAPEP6; HPLC confirmed conversion of NOTA-PEP6 to NOTA-PEP5 in the presence of TCEP. A $2 \mu \mathrm{g} / \mu \mathrm{L}$ solution of NOTA-PEP in PBS was treated with a $0.5 \mathrm{M}$ solution of TCEP (100X concentration) to a final concentration of $5 \mathrm{mM}$. The reaction was heated for 1 hour at $37^{\circ} \mathrm{C}$ and $10 \mu \mathrm{L}$ aliquot was injected on the HPLC. The TCEP treatment converted $60 \%$ of NOTA-PEP6 to NOTA-PEP5.

\section{B. Radiochemistry:}

$80 \mu \mathrm{g}$ of NOTA-PEP $(2 \mu \mathrm{g} / \mu \mathrm{L}$ concentration) was diluted into $160 \mu \mathrm{L}$ of sodium acetate buffer $(\mathrm{pH}=5.5)$ and added to ${ }^{68} \mathrm{GaCl} 3$ solution ( $370-740 \mathrm{MBq}$ in $4 \mathrm{~mL} 0.05 \mathrm{M} \mathrm{HCl}$; eluted from a generator). The mixture was tested for $\mathrm{pH}$ and additional sodium acetate buffer $(\mathrm{pH}=5.5)$ was added to modulate the $\mathrm{pH}$ to between 3.5-4. The mixture was heated to $90^{\circ} \mathrm{C}$ for 15 minutes, diluted with $50 \mathrm{mM}$ ammonium acetate solution and loaded onto a preconditioned C18 Sep-Pak. The cartridge was washed with $50 \mathrm{mM}$ ammonium acetate solution and the labelled peptide was eluted from the cartridge in $200 \mu \mathrm{L}$ fractions with $70: 30$ ethanol/50 mM ammonium acetate solution. The most concentrated fraction was diluted 10 -fold with $0.9 \%$ sodium chloride solution and passed through a sterile filter for use. ${ }^{68}$ Ga-NOTA-PEP4 was obtained $63 \%$ yield (decay corrected, $n=8$ ) in greater than $99 \%$ purity $(n=8)$, with molar activity greater than or equal to $15.6 \mathrm{GBq} / \mu \mathrm{mol}$. 

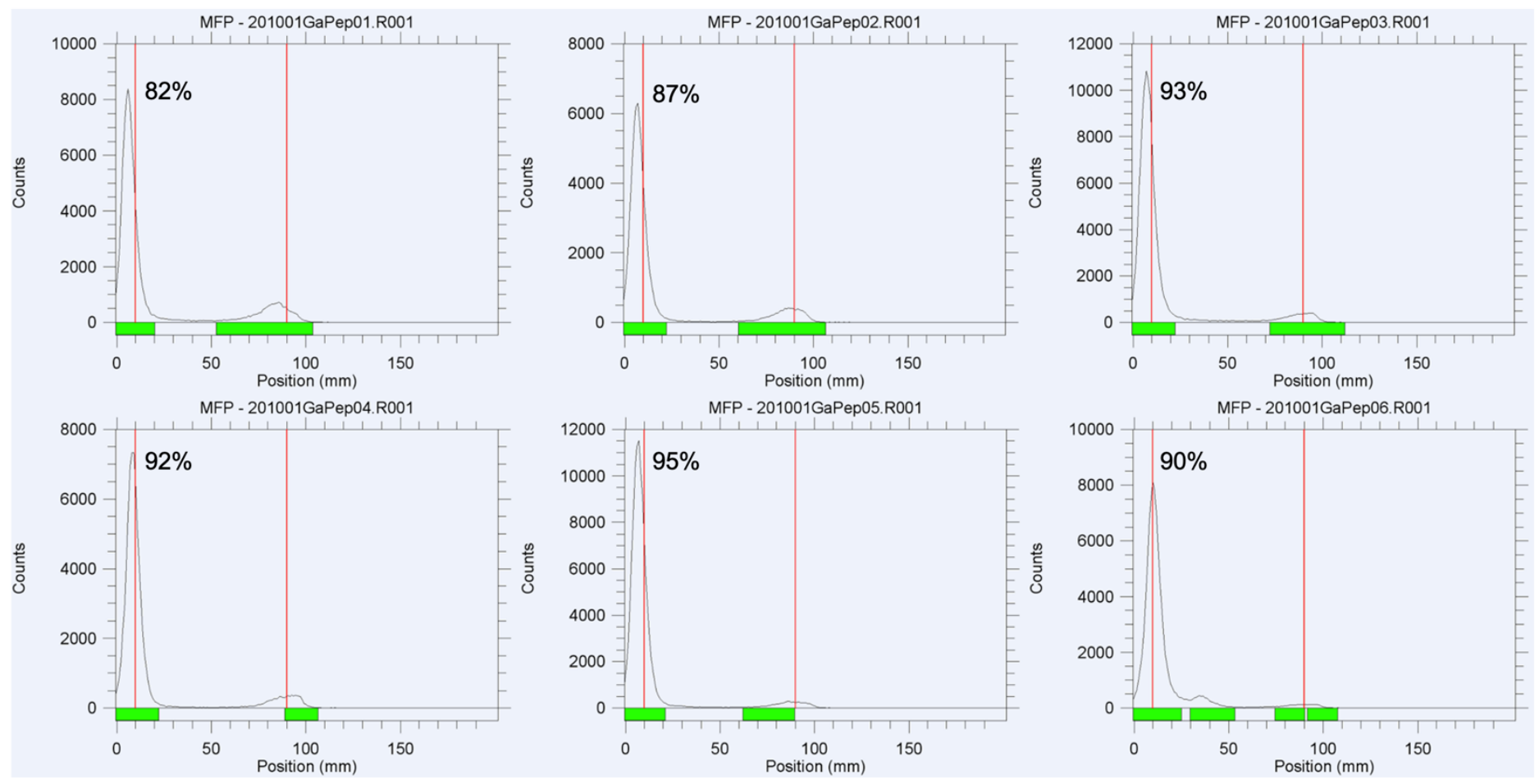

Supp. Fig. 3: Radiosyntheses of all six ${ }^{68} \mathrm{Ga}-N$ OTA-PEP peptides (crude RadioTLC). The chelated ${ }^{68} \mathrm{Ga}-$ NOTA-PEP was $>80 \%$ of radioactive signals observed in the crude product, in all cases.
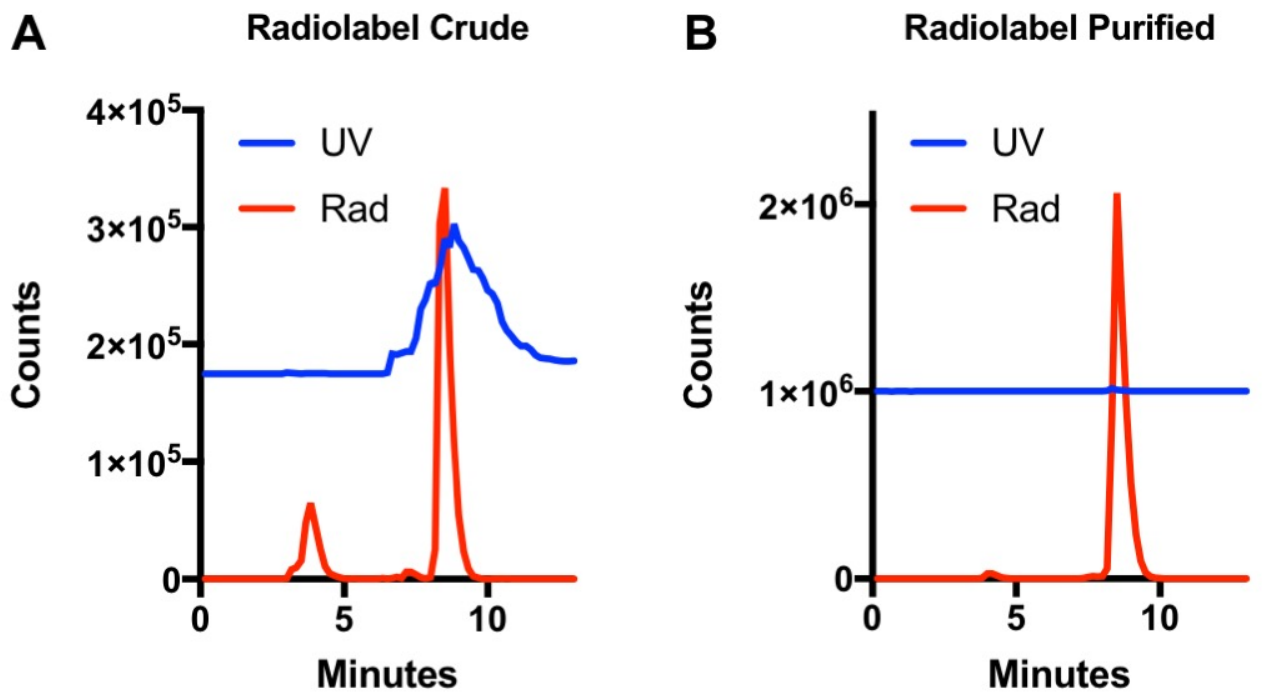

Supp. Fig. 4. A) HPLC (C18; gradient of 5-95\% $\mathrm{MeCN}$ in $\mathrm{H}_{2} 0$ ) of crude ${ }^{68} \mathrm{Ga}-\mathrm{NOTA}$-PEP4 after incubation of NOTA-PEP4 with ${ }^{68} \mathrm{Ga}_{-} \mathrm{GaCl}_{3}$. B) HPLC (C18; gradient of 5-95\% $\mathrm{MeCN}$ in $\left.\mathrm{H}_{2} \mathrm{O}\right)$ of purified ${ }^{68} \mathrm{Ga}-\mathrm{NOTA}-\mathrm{PEP} 4$ after purification on C18 sep-pak. Analysis of the purified trace shows $99 \%$ purity of the labeled peptide which was used subsequently for animal studies.

\section{Supplemental Figures:}


A Stability in PBS

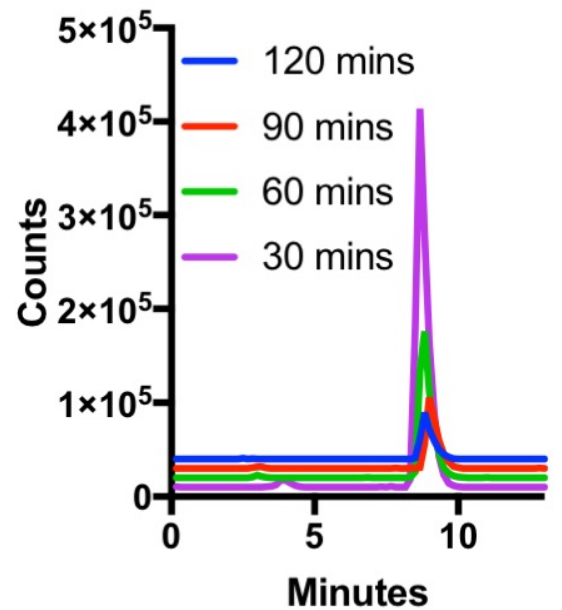

B Stablity in Mouse Serum

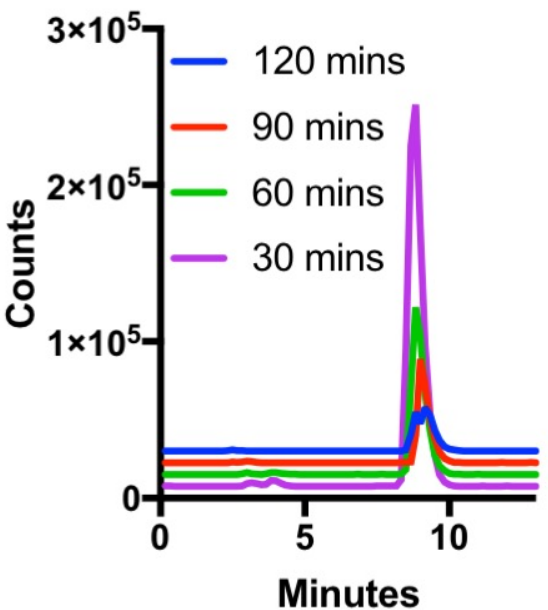

C Stability in Human Serum

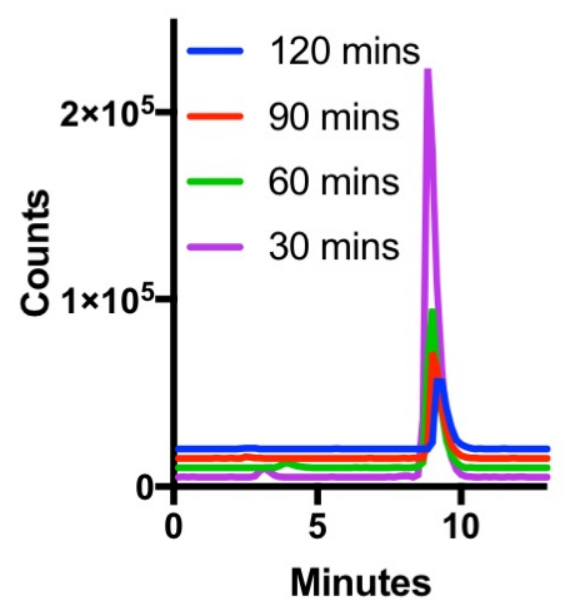

Supp. Fig. 5. HPLC C18; gradient of 5-95\% $\mathrm{MeCN}$ in $\mathrm{H}_{2} 0$ ) analysis of ${ }^{68} \mathrm{Ga}-\mathrm{NOTA}$-PEP4 incubated with PBS, mouse serum, and human serum. $37 \mathrm{MBq}(1 \mathrm{mCi})$ of ${ }^{68} \mathrm{Ga}-\mathrm{NOTA}$-PEP4 was added to $1 \mathrm{~mL}$ of each solution and incubated for 2 hours at $37^{\circ} \mathrm{C}$. HPLC were performed at 30 min intervals. ${ }^{68} \mathrm{Ga}-N O T A-P E P 4$ was $>95 \%$ intact in each solution for the 2 hour duration. 
Coronal

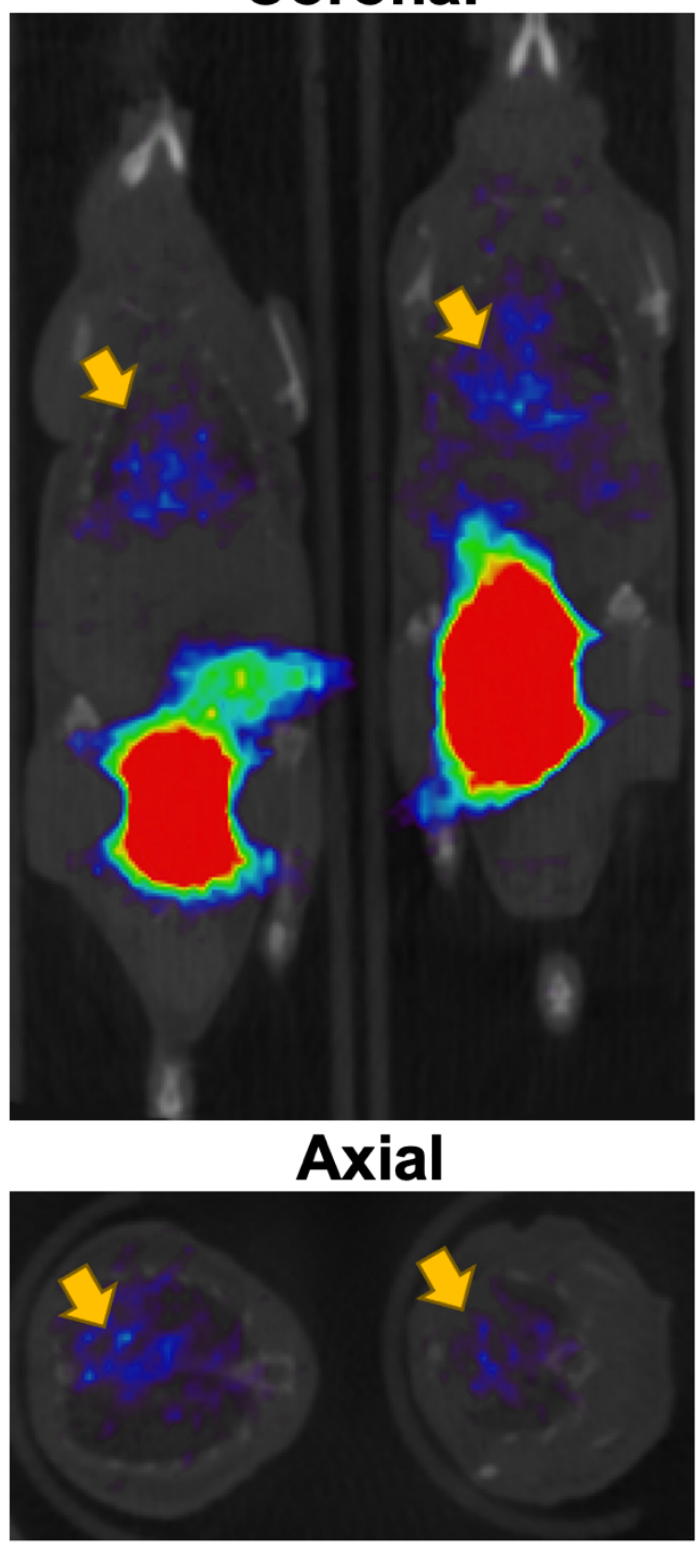

Sagittal

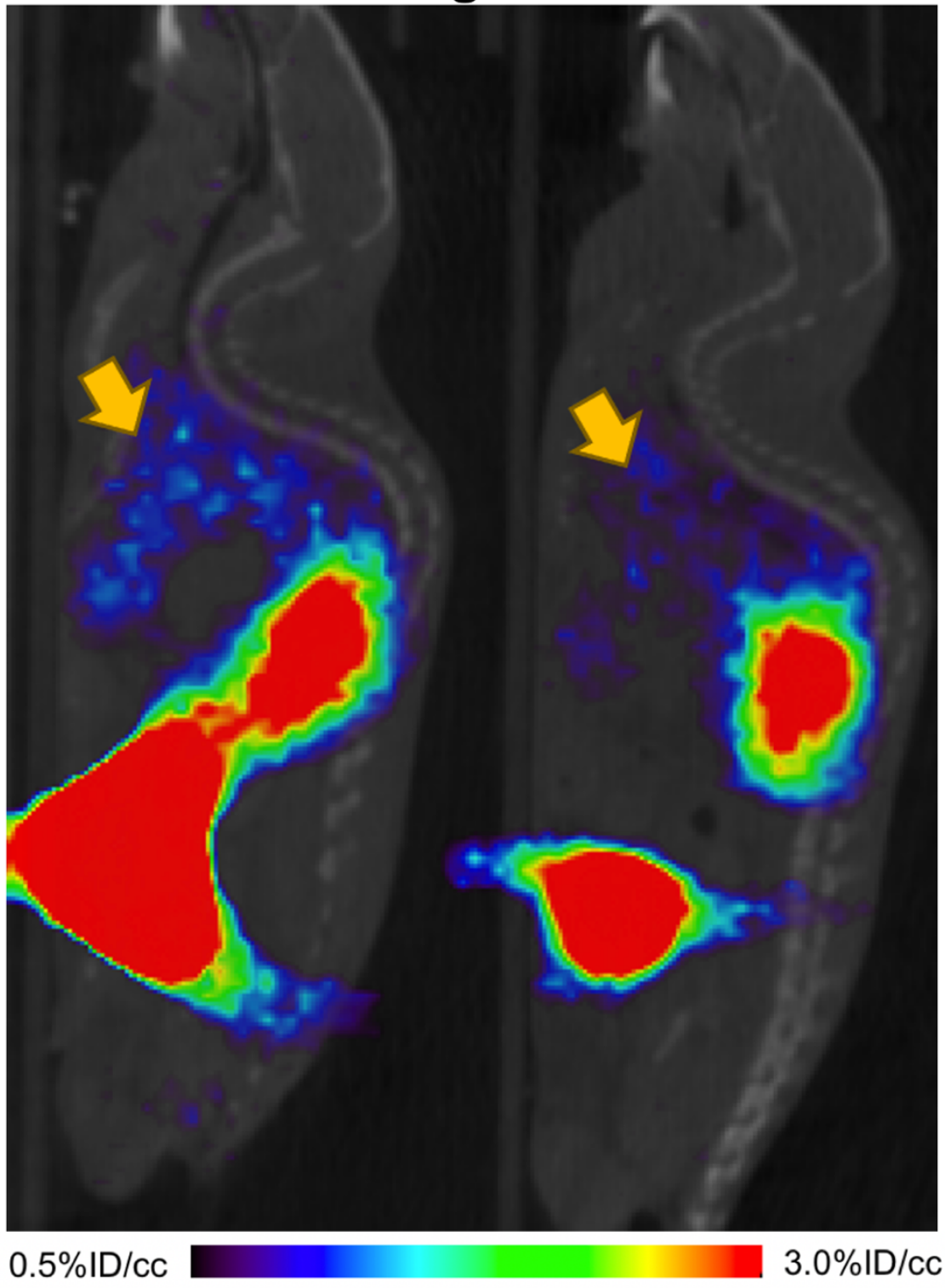

Supp. Fig. 6: Additional images of ${ }^{68}$ Ga-NOTA-PEP4 in hACE2 transgenic mice, obtained via single time-point acquisition. 


\section{Ex Vivo ACE2 Activity of Tissue Isolates}

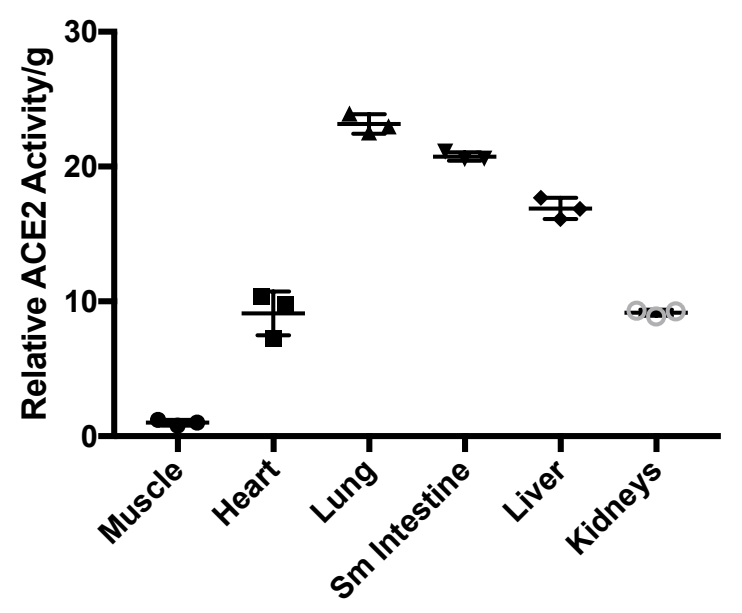

Supp. Fig. 7: Confirmation of ACE2 activity in tissue isolates, as correlation to reported in vivo data (Anaspec, Fremont CA). 


\section{Eurogentec}

ANASPEC PEPTIDE QC Data Sheet

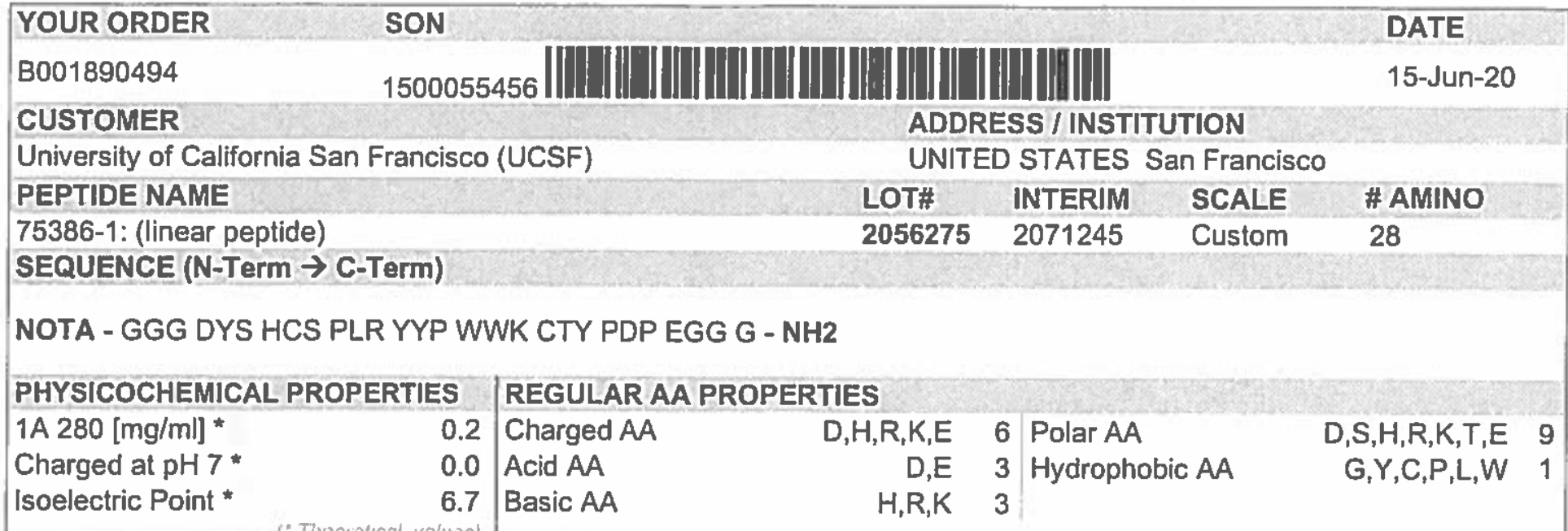

\section{QC DATA}

\section{Attribute}

Appearance

$\%$ Peak Area by HPLC

Identity

DELIVERABLE

Format

Test method
Visual
HPLC
MS

MS

Acceptance criteria
Report result
$\geq 90 \%$
$3433.9 \pm 0.2 \%$

Acceptance criteria

$\geq 90 \%$
Aliquoting

Number of Aliquots 1

Qty by Aliquot (mg) $10 \mathrm{mg}$

STORAGE CONDITION

$-20^{\circ} \mathrm{C}$ dry

\section{Result \\ White Powder \\ $96 \%$ \\ 3435.1}

\section{DELIVERY CONDITION}

Room temperature COMMENTS

\section{PEPTIDE RECONSTITUTION AND STORAGE}

Piease read the entire section before proceeding with the solubilization of your custom peptide.

Peptldes are shipped at ambient temperature as a lyophilized powder. Upon receipt store them at $-20^{\circ} \mathrm{C}$. Allow the vial to equilibrale to roorn temperature prior to opening.

Peptide solubility is highly dependent on the sequence. Peptides that are more hydrophobic (high propensity of $A, F, G, V, L, I, M, W, P$ ) in nature, will require an organic solvent in order to dissolve. Peptides that are acidic in nature (high propensity of $D$, $E$ in the peplide sequence) require a basic aqueous buffer to dissolve, while peptides that are basic in nature (high propensity of $\mathrm{K}, \mathrm{H}$, and $\mathrm{R}$ ) require an acidic aqueous buffer to dissolve.

To reconstitute a hydrophobic peptide, add $100 \mu \mathrm{L}$ DMSO and sonicate until a homogenous solution forms. Next, add your buffer of cholce to form a $1 \mathrm{mg} / \mathrm{mL}$ solution (a higher concentration of peptide will require a greater amount of DMSO). To reconslitule basic or acidic peptides, add $1 \mathrm{~mL}$ of the appropriate buffer to the peptide and sonicate to ensure a homogenous solution forms.

Reconstituted peptides can be stored frozen at $-20^{\circ} \mathrm{C}$ for short perlod of time, but it is advisable to prepare multiple aliquots lo avoid multiple freeze thaw cycles. We recommend that all aliquoled solutions be lyophilized if the peplide is going to be stored for extended periods of time at $-20^{\circ} \mathrm{C}$.

Additionally, please note that peptides with a high propensity of basic residues $(R, K, H)$ in their sequence may undergo a physical change from solid powder to an oil (via moisture absorption). This physical change does not affect the purity or functionality of the peptide.

Nomenclature used for the sequence termini:

N-terminus: $\mathrm{H}$ means free amine ( $\mathrm{NH}_{2}-$ ), Ac mean acelyl [CH3C(O)-NH-], Pyr means pyroglutamic acid

C-leminus: $\mathrm{OH}$ means free acid $(-\mathrm{COOH}), \mathrm{NH}_{2}$ means amide [-CONH$\left.{ }_{2}\right]$

Modifications on the side chain of amino acids are depicted in the parenthesis after the corresponding amino acid. For example; phosphorylated serine $=\mathrm{S}\left(\mathrm{PO} \mathrm{H}_{2}\right)$ or epsilon-N-acetylated lysine $=\mathrm{K}(\mathrm{Ac})$

TECHNICAL SUPPORT

If you have any questions feel free to call our Technical Support Centre

\section{EUROPE}

(d) 0080066600123 (European toll free number),

区info@eurogentec.com

Kaneka Eurogentec S.A. LIege Sclence Park

Rue Bois Saint-Jean 5-4102 SERAING BELGIUM

Tel: +32(0)4 3727400 - Fax: $+32(0) 4264078 \mathrm{~B}$

E-mail: infogevurogentec.con Web: whw, eurogentec, con

RPM LAgge T.V.A.-(BE)-0427.348.346 - ING Belgique Bank - IBAN: BEB6 340021186050 BIC: BERUBEBB

\section{NORTH AMERICA}

(2) $+1800452-5530$ (American toll free number).

\$ service@anaspec.com

AnaSpec, Inc. 34801 Campus Drive

Fremont, CA 94555 - USA

Tel.$:+1$ (510) 79 † 9560 - Fax: +1 510 (791) 9572

E-mall: gervicegeutagenlec.com Web wmw. anaspec.com 


\begin{tabular}{|c|c|c|c|}
\hline & Chromatogram and Resu & & \\
\hline Injection Detałls & & & \\
\hline Injection Name: & 2071245 & Run Time (min) & 12.00 \\
\hline Vial Number: & GA1 & Injection Volume: & 1.00 \\
\hline Injection Type: & Unknown & Channel: & UV VIS 1 \\
\hline Column: & $\mathrm{C} 18,100 \times 4.6 \mathrm{~mm}, \mathrm{H} 17-231434$ & Wavelength: & $220^{-}-$ \\
\hline Injection Date/Time: & 15/Jun/20 11:31 & Sample Weight: & \\
\hline
\end{tabular}

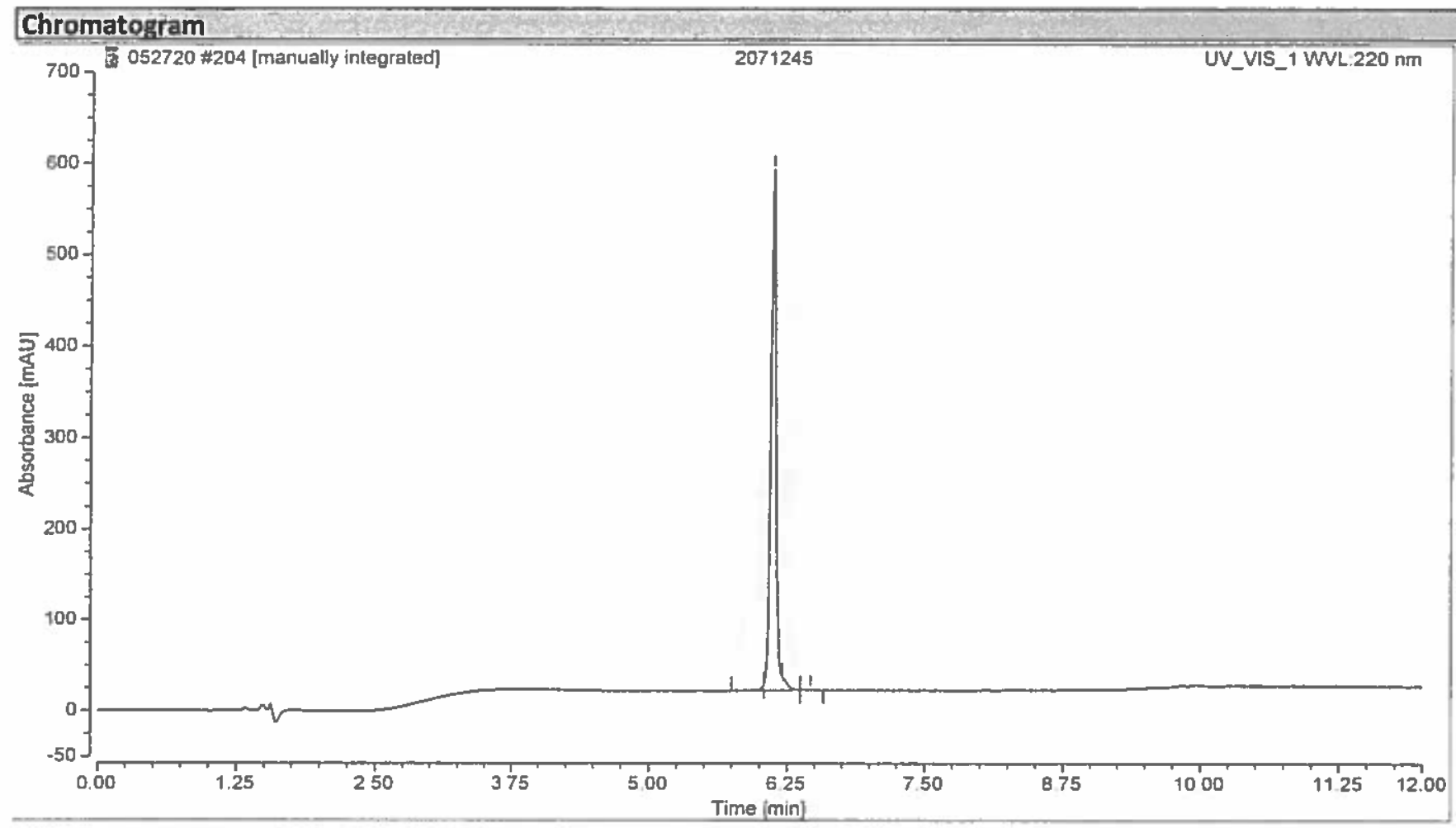

\begin{tabular}{|l|c|c|c|c|}
\hline \multicolumn{2}{|l|}{ Integration Results } & & \\
\hline No. & $\begin{array}{c}\text { Retention Time } \\
\text { min }\end{array}$ & $\begin{array}{c}\text { Area } \\
\text { mAU*min }\end{array}$ & $\begin{array}{c}\text { Height } \\
\text { mAU }\end{array}$ & $\begin{array}{c}\text { Relative Area } \\
\%\end{array}$ \\
\hline 1 & 6.040 & 0.204 & 6.008 & 0.64 \\
2 & 6.120 & 30.586 & 571.320 & 96.41 \\
3 & 6.207 & 0.807 & 15.001 & 2.55 \\
4 & 6.463 & 0.128 & 1.142 & 0.40 \\
\hline Total: & & 31.724 & 593.470 & 100.00 \\
\hline
\end{tabular}




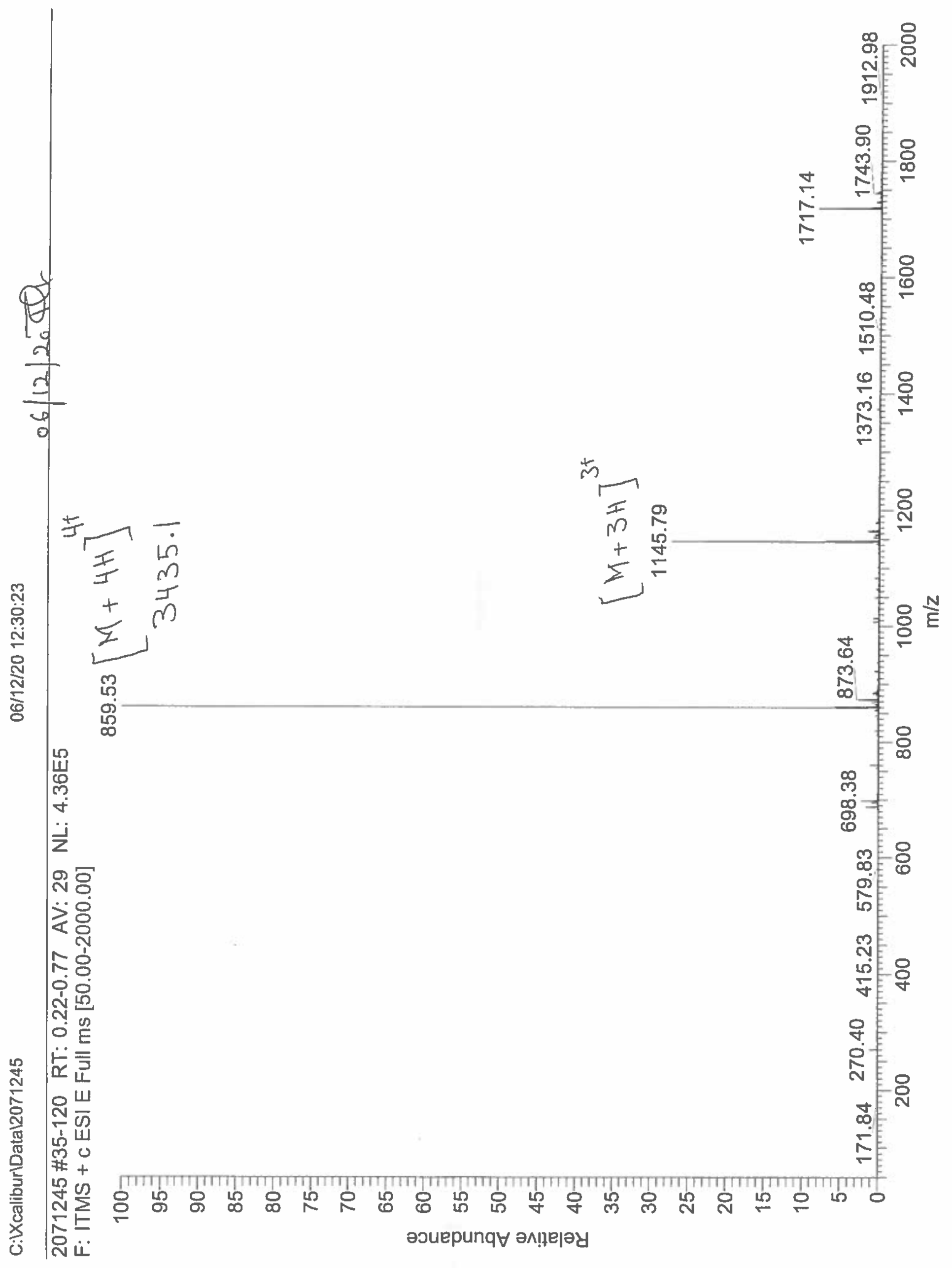




\section{Eurogentec}

\begin{tabular}{|c|c|c|c|c|c|c|c|}
\hline YOUR ORDER & & & & & & DATE & \\
\hline B001890494 & & & & & & 16-Jun-20 & \\
\hline CUSTOMER & & ADD & ES & SS / INSTI & JTION & & \\
\hline University of California San Francisco & (UCSF) & UNIT & E & STATES & an Francisc & & \\
\hline PEPTIDE NAME & & LOT\# & & INTERIM & SCALE & \# AMINO & \\
\hline 75386-2: (disulfide bridge) & & 2056276 & & 2071246 & Custom & 28 & \\
\hline SEQUENCE (N-Term $\rightarrow$ C-Term) & & & & & & & \\
\hline NOTA - GGG DYS HC(S-)S PLR YYF & WWK C(S-)T & G-NH2 & & disulfide $b$ & & & \\
\hline PHYSICOCHEMICAL PROPERTIES & REGULAR A & RTIES & & & & & \\
\hline $1 \mathrm{~A} 280[\mathrm{mg} / \mathrm{ml}]^{*} \quad 0.2$ & Charged AA & $D, H, R, K, E$ & 6 & Polar AA & & $D, S, H, R, K, T, E$ & 9 \\
\hline Charged at $\mathrm{pH} 7$ * & Acid AA & D,E & 3 & Hydropho & ic $A A$ & $G, Y, P, L, W$ & 1 \\
\hline $\begin{array}{r}6.7 \\
\text { ("Theorotical viluas! }\end{array}$ & Basic AA & $H, R, K$ & 3 & & & & \\
\hline
\end{tabular}

\section{QC DATA}

\section{Attribute}

Appearance

\% Peak Area by HPLC

Identity

DELIVERABLE

Format

\section{DELIVERY CONDITION}

Room temperature COMMENTS

Acceptance criteria
Report result
$\geq 95 \%$
$3431.9 \pm 0.2 \%$

Test method

Visual

HPLC

MS
Dried

\section{Result \\ White Powder \\ $95 \%$ \\ 3432.6}

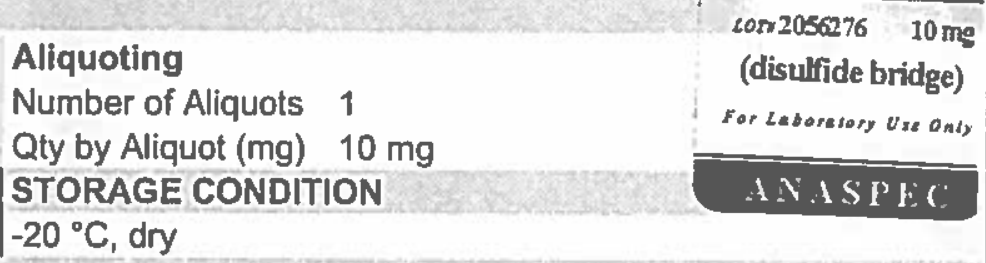

\section{PEPTIDE RECONSTITUTION AND STORAGE}

Please read the entire section before proceeding with the solubilization of your custom peptide.

Peptides are shipped at ambient temperature as a lyophilized powder. Upon receipt store them at $-20^{\circ} \mathrm{C}$. Allow the vial to equilibrate to room temperature prior to opening.

Peptide solubility is highly dependent on the sequence. Peptides that are more hydrophobic (high propensity of $A, F, G, V, L, I, M, W, P$ ) in nature, will require an organic solvent in order to dissolve. Peptides that are acidic in nature (high propensity of $\mathrm{D}$. $E$ in the peptide sequence) require a basic aqueous buffer to dissolve, while peptides that are basic in nature (high propensity of $\mathrm{K}, \mathrm{H}$, and $\mathrm{R}$ ) require an acidic aqueous buffer to dissolve.

To reconstitule a hydrophobic peptide, add $100 \mu \mathrm{L}$ DMSO and sonicate until a homogenous solution forms. Next, add your buffer of choice to form a $1 \mathrm{mg} / \mathrm{mL}$ solution (a higher concentration of peptide will require a greater amount of DMSO). To reconstitute basic or acidic peptides, add $1 \mathrm{~mL}$ of the appropriate buffer to the peptide and sonicate to ensure a homogenous solution forms.

Reconstituted peptides can be stored frozen at $-20^{\circ} \mathrm{C}$ for short period of time, but it is advisable to prepare multiple aliquots to avoid multiple freeze thaw cyctes. We recommend that all aliquoled solutions be lyophilized if the peptide is going to be stored for extended periods of time at $-20^{\circ} \mathrm{C}$.

Additionally, piease note that peptides with a high propensity of basic residues $(R, K, H)$ in their sequence may undergo a physical change from solid powder to an all (via moisture absorption). This physical change does not affect the purity or functionality of the peptide.

Nomenclature used for the sequence termini:

N-leminus: $\mathrm{H}$ means free amine ( $\mathrm{NH}_{2}-$ ), Ac mean acetyl [CH3C(O)-NH-], Pyr means pyroglutamic acid

C-terminus: $\mathrm{OH}$ means free acid (-COOH), $\mathrm{NH}_{2}$ means amide [-CONH $\left.\mathrm{H}_{2}\right]$

Modificalions on the side chain of amino acids are depicted in the parenthesis after the corresponding amino acid. For example; phosphorylated serine $=\mathbf{S}\left(\mathrm{PO}_{3} \mathrm{H}_{2}\right)$ or epsilon-N-acetylated lysine $=K(A C)$

TECHNICAL SUPPORT

If you have any questions feel free to call our Technical Support Centre

\section{EUROPE}

(D) 0080066600123 (European toll free number),

\section{info@eurogentec.com}

Kaneka Eurogentec S.A. Uäge Science Park

Rue Bois Saint-Jean 5 - 4102 SERAING BELGIUM

Tel: $+32(0) 43727400-$ Fax: $+32(0) 42640788$

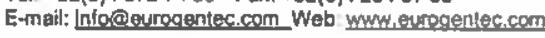

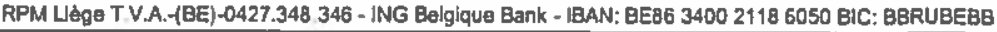

\section{NORTH AMERICA}

Q +1 800 452-5530 (American toll free number),

四 service@anaspec.com

AnaSpec, Iruc, 34801 Campus Drive

Fremonl, CA 94555 - USA

Tel.: +1 (510) $7919560-\mathrm{Fax}_{\text {; }}+1510$ (791) 9572

E-mali: serwice@erumantec.con Web umw.anaspec.com 


\begin{tabular}{|c|c|c|c|}
\hline \multicolumn{4}{|c|}{ Chromatogram and Results } \\
\hline \multicolumn{4}{|l|}{ Injection Details } \\
\hline Vial Number: & GC2 & Injection Volume: & 1.00 \\
\hline Injection Type: & Unknown & Channel & UV_VIS_1 \\
\hline Column: & $\mathrm{C} 18,100 \times 4.6 \mathrm{~mm}, \mathrm{H} 17-231434$ & Wavelength: & $220-$ \\
\hline Injection Date/Time: & 16/Jun/20 13:47 & Sample Weight: & \\
\hline
\end{tabular}

Chromatogram

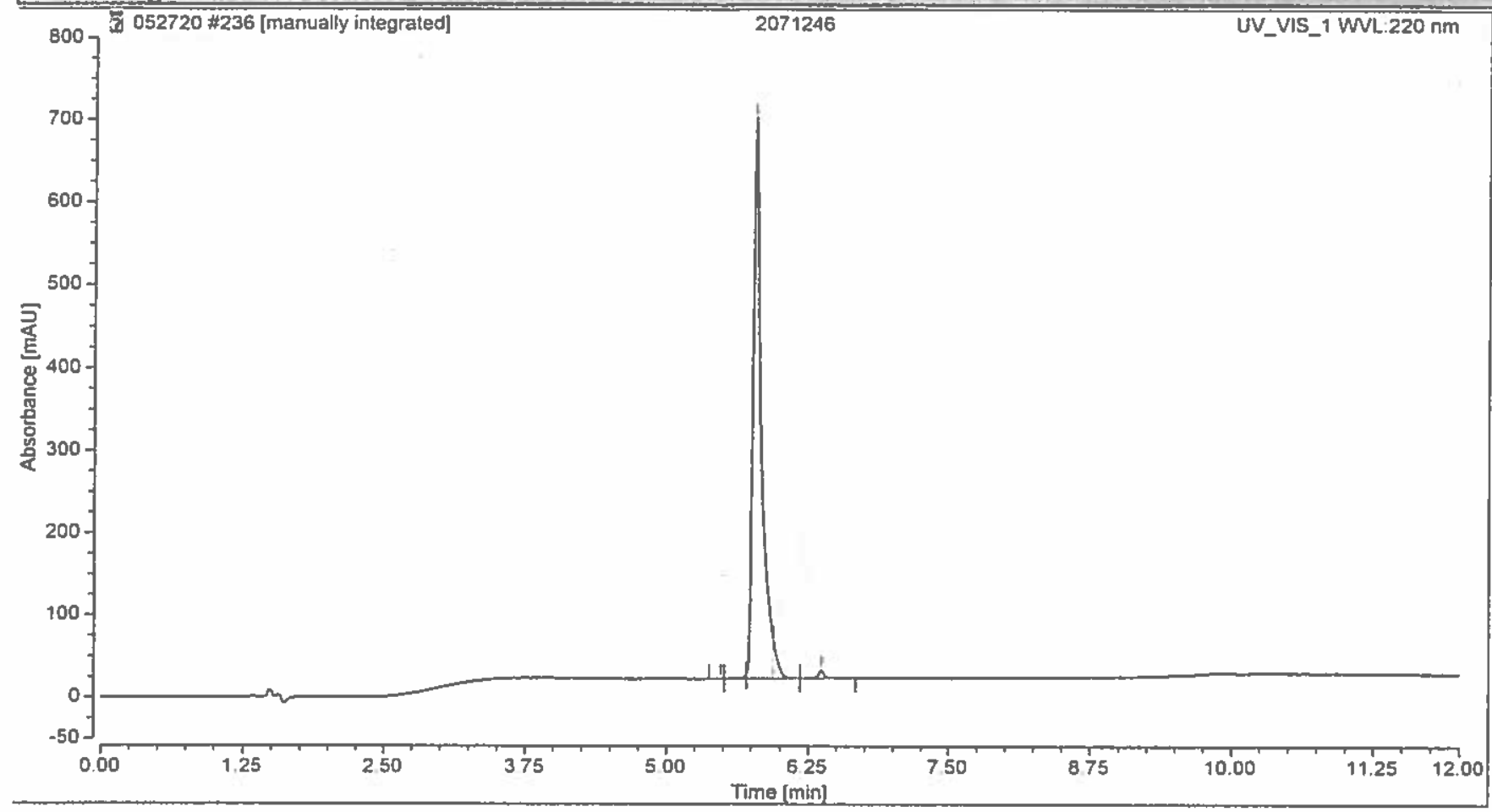

\begin{tabular}{|l|c|c|c|c|}
\hline \multicolumn{4}{|l|}{ Integration Results } & \multicolumn{3}{l|}{} \\
\hline No. & $\begin{array}{c}\text { Retention Time } \\
\text { min }\end{array}$ & $\begin{array}{c}\text { Area } \\
\text { mAU*min }\end{array}$ & $\begin{array}{c}\text { Height } \\
\text { mAU }\end{array}$ & $\begin{array}{c}\text { Relative Area } \\
\%\end{array}$ \\
\hline 1 & 5.477 & 0.003 & 0.104 & 0.01 \\
2 & 5.707 & 0.096 & 3.887 & 0.17 \\
3 & 5.773 & 55.557 & 679.939 & 95.33 \\
4 & 5.937 & 2.010 & 47.591 & 3.45 \\
5 & 6.367 & 0.611 & 10.131 & 1.05 \\
\hline Total: & & 58.277 & 741.651 & 100.00 \\
\hline
\end{tabular}




\section{Eurogentec}

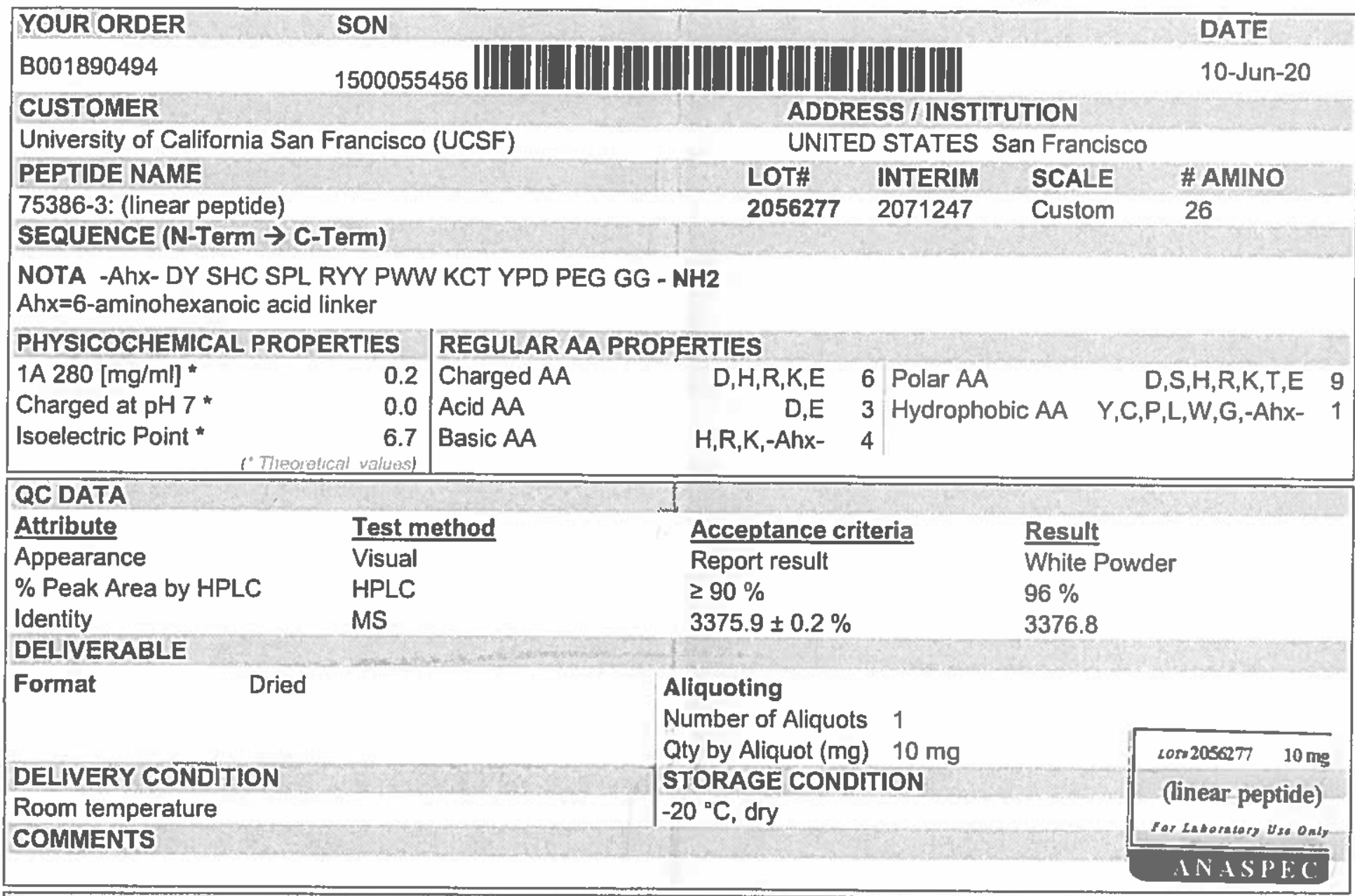

\section{PEPTIDE RECONSTITUTION AND STORAGE}

Please read the entire section before proceeding with the solubilization of your custom peptide.

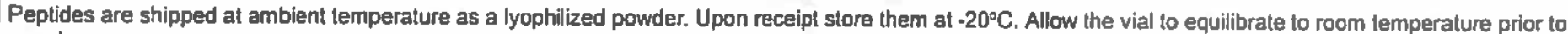
opening.

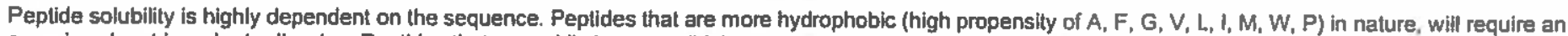

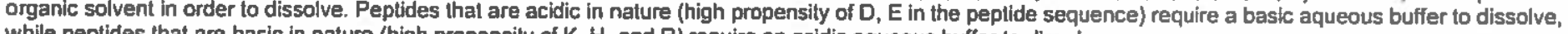
while peptides that are basic in nature (high propensily of $K, H$ and $R$ ) require an acidic aqueous buffer to dissolve.

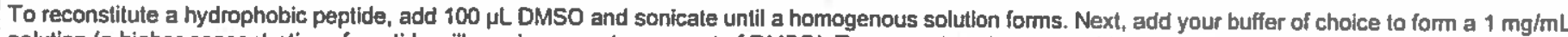

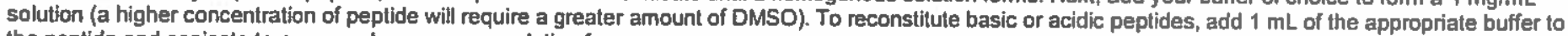
the peptide and sonicate to ensure a homogenous solution foms.

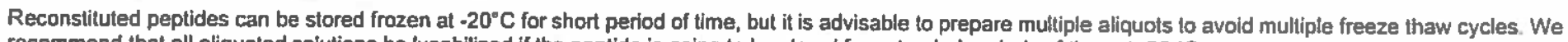
recommend that all aliquoted solutions be lyophilized if the peptide is going to be stored for extended periods of time at $-20^{\circ} \mathrm{C}$.

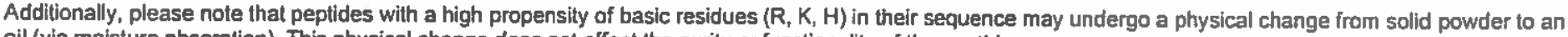
oil (via moisture absorplion). This physical change does not affect the purity or functionality of the peptide.

Nomenclature used for the sequence temini:

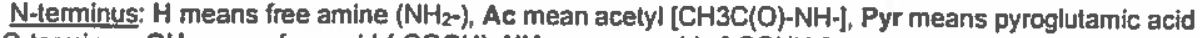

C-terminus; $\mathrm{OH}$ means free acid $(-\mathrm{COOH}), \mathrm{NH}_{2}$ means amide [-CONH $\left.\mathrm{H}_{2}\right]$

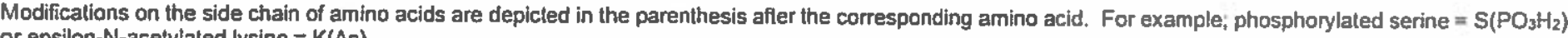
or epsilon-N-acelylated lysine $=\mathrm{K}(\mathrm{Ac})$

TECHNICAL SUPPORT

If you have any questions feel free to call our Technical Support Centre

\section{EUROPE}

D. 0080066600123 (European toll free number),

函fo@eurogentec.com

Kaneka Eurogenlec S.A. Uáge Science Park

Rue Bois Saint-Jean 5 - 4102 SERAING BEL,GIUM

Tel: $+32(0) 43727400-\mathrm{Fax}$ + 32 (0)4 2640788

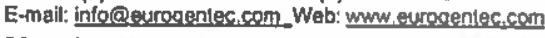

RPM Líge TVA.-(BE)-0427.348.346 - ING Belgique Bank = IEAN: BE:6 3400 2118 6050 BIC: BBRUBEBB

\section{NORTH AMERICA}

O) $+1800452-5530$ (American toll free number),

区 service@anaspec.com

AnaSpec, Inc 3480: Campus Drive

Fremont, CA 94555 - USA

Tel: +1 (510) 7919560 - Fax +1510 (791) 9572

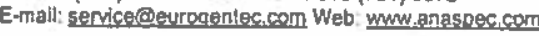




\begin{tabular}{|c|c|c|c|}
\hline & Chromatogram and Res & & \\
\hline Injection Details & & & \\
\hline Injection Name: & 2071247 & Run Time (min): & 12.00 \\
\hline Vial Number: & BA1 & Injection Volume: & 1.50 \\
\hline Injection Type: & Unknown & Channel: & UV_VIS_1 \\
\hline Column: & $\mathrm{C} 18,100 \times 4.6 \mathrm{~mm}, \mathrm{H} 17-231434$ & Wavelength: & $220^{-}$ \\
\hline Injection Date/Time: & 10/Jun/20 13:56 & Sample Weight: & \\
\hline
\end{tabular}

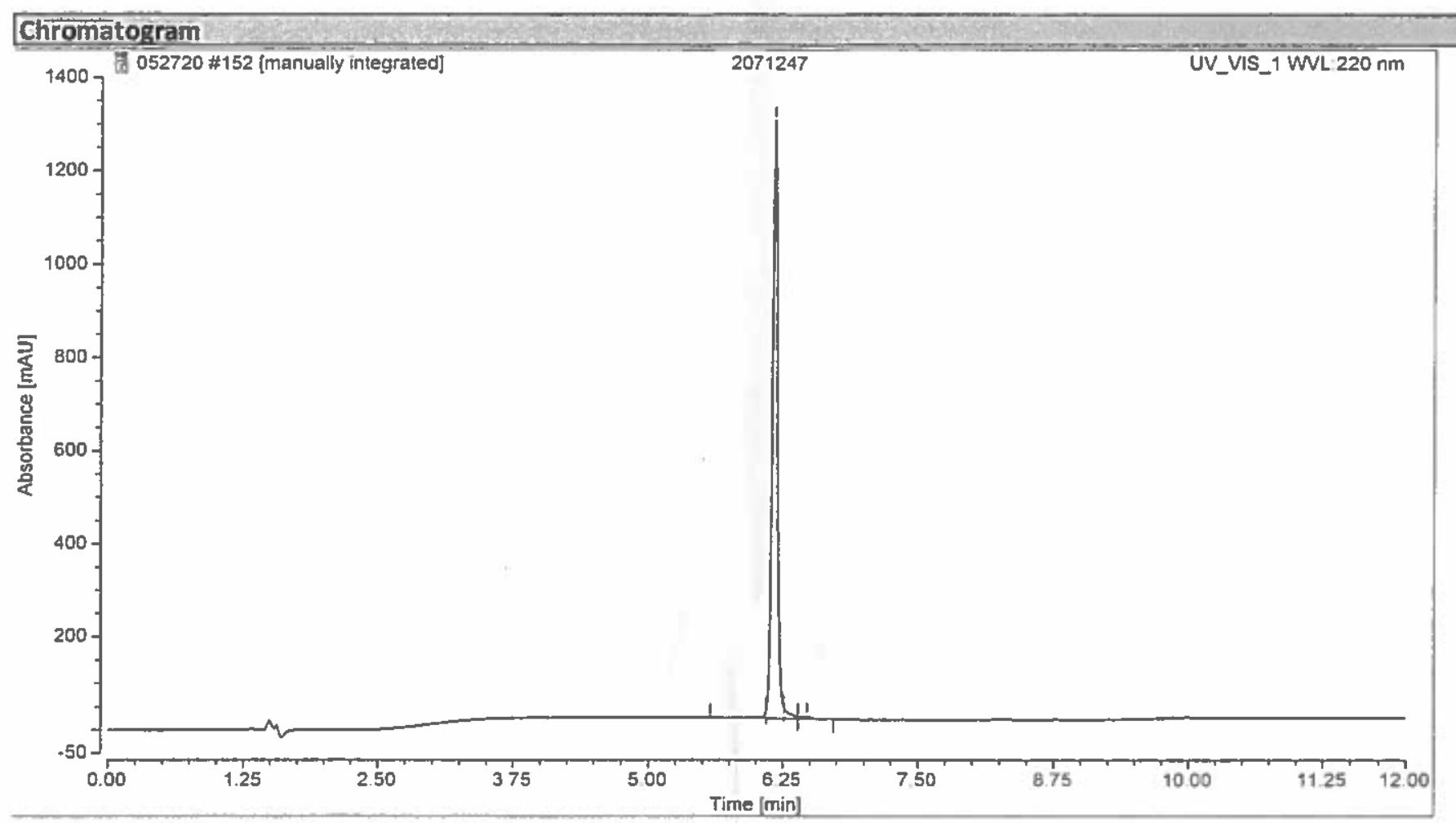

\begin{tabular}{|c|c|c|c|c|}
\hline \multicolumn{5}{|c|}{ Integration Results } \\
\hline No. & $\begin{array}{c}\text { Retention Time } \\
\text { min }\end{array}$ & $\begin{array}{c}\text { Area } \\
\text { mAU*min }\end{array}$ & $\begin{array}{l}\text { Height } \\
\text { mAU }\end{array}$ & $\begin{array}{c}\text { Relative Area } \\
\%\end{array}$ \\
\hline 1 & 6.097 & 0.652 & 16.476 & 091 \\
\hline 2 & 6.170 & 69.280 & 1283.037 & 96.41 \\
\hline 3 & 6.260 & 1.376 & 21.965 & 192 \\
\hline 4. & 6.473 & $0, \dot{5} 55$ & 5.212 & 0.77 \\
\hline \multicolumn{2}{|c|}{ Total: } & 71.863 & 1326.691 & 100.00 \\
\hline
\end{tabular}




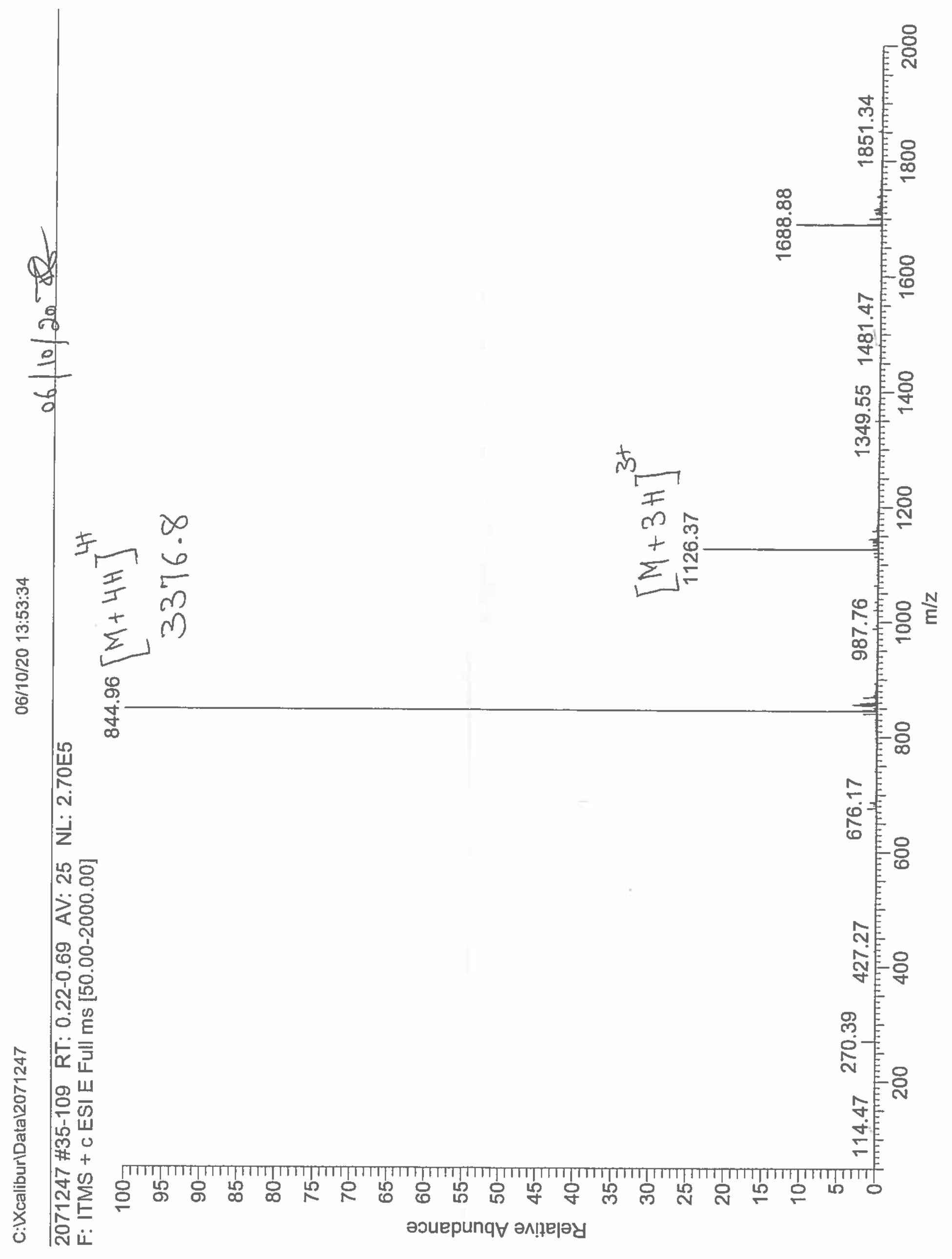




\section{Eurogentec}

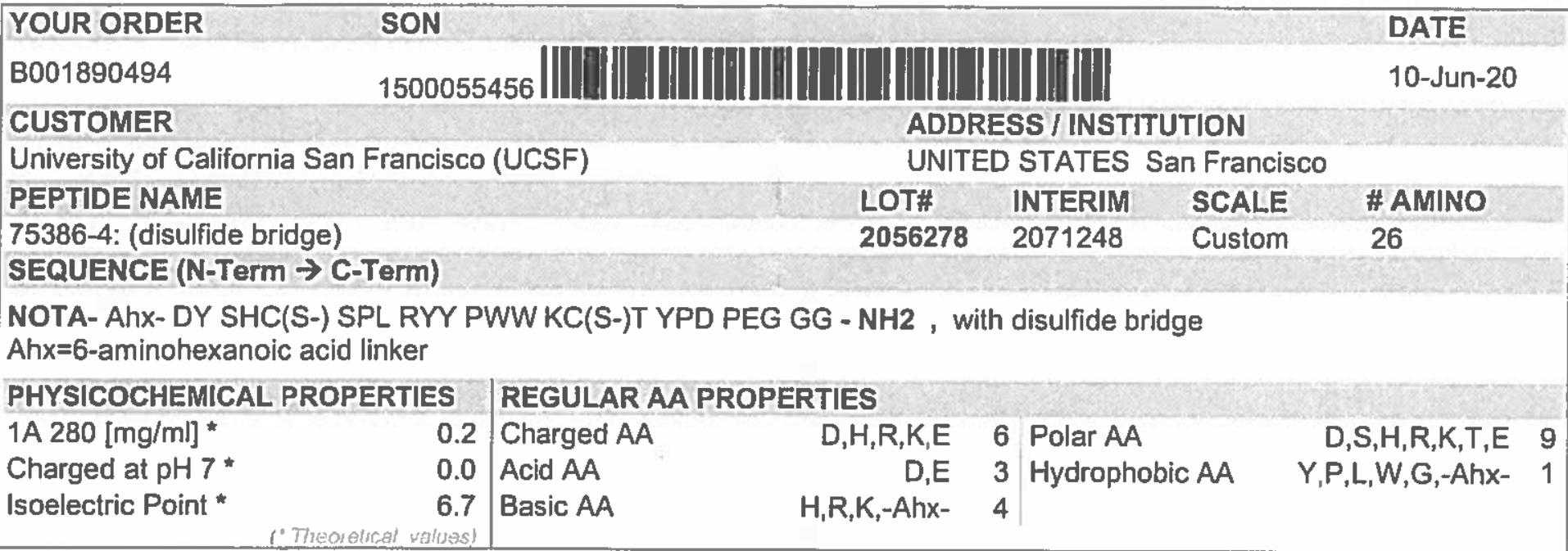

QC DATA

\section{Attribute}

Appearance

$\%$ Peak Area by HPLC

Identity

DELIVERABLE

Format

Dried

\section{Format}

\section{Acceptance criteria \\ Report result \\ $\geq 95 \%$ \\ $3373.8 \pm 0.2 \%$}

10-Jun-20

\section{ADDRESS / INSTITUTION}

SCALE

\# AMINO

26

\section{DELTVERY CONDDTION}

Room temperature

COMMENTS

\author{
Aliquoting \\ Number of Aliquots 1 \\ Qty by Aliquot (mg) $10 \mathrm{mg}$ \\ STORAGE CONDITION \\ $-20^{\circ} \mathrm{C}$, dry
}

\section{Result \\ White Powder \\ $95 \%$ \\ 3374.8}

\section{PEPTIDE RECONSTITUTION AND STORAGE}

Please read the entire section before proceeding with the solubilization of your custom peptide.

Peptides are shipped at ambient temperature as a lyophilized powder. Upon receipt store them at $-20^{\circ} \mathrm{C}$. Allow the vial to equilibrate to room temperature prior to opening.

Peptide solubility is highly dependent on the sequence. Peptides that are more hydrophobic (high propensity of $A, F, G, V, L, I, M, W, P$ ) in nature, will require an organic solvent in order to dissolve. Peptides that are acidic in nature (high propensity of $D$, E in the peptide sequence) require a basic aqueous buffer to dissolve, while peptides that are basic in nalure (high propensity of $\mathrm{K}, \mathrm{H}$, and $\mathrm{R}$ ) require an acidic aqueous buffer to dissolve.

To reconstitute a hydrophobic peptide, add $100 \mu \mathrm{L}$ DMSO and sonicale until a homogenous solution forms. Next, add your buffer of choice to form a $1 \mathrm{mg} / \mathrm{mL}$ solution (a higher concentration of peptide will require a greater amount of DMSO). To reconstitute basic or acidic peptides, add $1 \mathrm{~mL}$ of the appropriate buffer to the peptide and sonicale to ensure a homogenous solution forms.

Reconstituted peptides can be stored frozen at $-20^{\circ} \mathrm{C}$ for short period of time, but it is advisable to prepare multiple aliquots to avoid multiple freeze thaw cycles. We recommend that all aliquoted solutions be lyophilized if the peplide is going to be stored for extended periods of time at $-20^{\circ} \mathrm{C}$.

Additionally, please note that peptides with a high propensity of basic residues $(R, K, H)$ in their sequence may undergo a physical change from solid powder to an oil (via moisture absorption). This physical change does not affect the purity or funclionality of the peptide.

Nomenclature used for the sequence termini:

N-terminus: $\mathrm{H}$ means free amine $\left(\mathrm{NH}_{2}-\right)_{1}$ Ac mean acelyl [CH3C(O)-NH-], Pyr means pyroglutamic acid

C.terminus: $\mathrm{OH}$ means free acid $(-\mathrm{COOH}), \mathrm{NH}_{2}$ means amide [- $\left.\mathrm{CONH} \mathrm{H}_{2}\right]$

Modifications on the side chain of amino acids are depicted in the parenthesis after the corresponding anaino acid. For example; phosphorylated serine $=\mathrm{S}\left(\mathrm{PO} \mathrm{H}_{2}\right)$ or epsilon- $\mathrm{N}$-acetylated lysine $=\mathrm{K}(\mathrm{Ac})$

\section{TECHNICAL SUPPORT}

If you have any questions feel free to call our Technical Support Centre

EUROPE

() 0080066600123 (European toll free number).

国 info@eurogentec.com

Kaneka Eurogentec S.A. Liage Science Park

Rue Bois Saint-Jean 5 - 4102 SERAING BELGIUM

Tel: $+32(0) 43727400-$ Fax: $+32(0) 42640788$

E-maili inforeurogentec.com_Wob inwweurogentec.com

RPM Litge T.VA.-fBE)-0427,348,346 - ING Belgique Bank - IBAN: BEB6 340021186050 BIC BBRUBEB日

\section{NORTH AMERICA}

(1) $+1800452-5530$ (American toll free number),

$\otimes$ service@anaspec.com

AnaSpec, Inc 34801 Campus Drive

Fremont, CA 94555 - USA

Tel. +1 (510) $7919560-$ Fax: +1510 (791) 9572

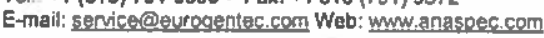




\begin{tabular}{|c|c|c|c|}
\hline \multicolumn{4}{|c|}{ Chromatogram and Results } \\
\hline \multicolumn{4}{|l|}{ Injection Details } \\
\hline Injection Name & 2071248 & Run Time (min): & 12.00 \\
\hline Vial Number: & BA2 & Injection Volume: & 2.50 \\
\hline Injection Type: & Unknown & Channel: & UV_VIS_1 \\
\hline Column: & $\mathrm{C} 18,100 \times 4.6 \mathrm{~mm}, \mathrm{H} 17-231434$ & Wavelength & 220 \\
\hline Instrument Method: & 5-60\%B-7minsExtended,Column(6-1)-0.7ml-30C & Bandwidth & 4 \\
\hline Processing Method: & test & Instrument No. & QC-HPLC-10 \\
\hline Injection Dafe/Time: & $10 / \mathrm{Jun} / 20$ 15:31 & Sample Weight: & \\
\hline
\end{tabular}

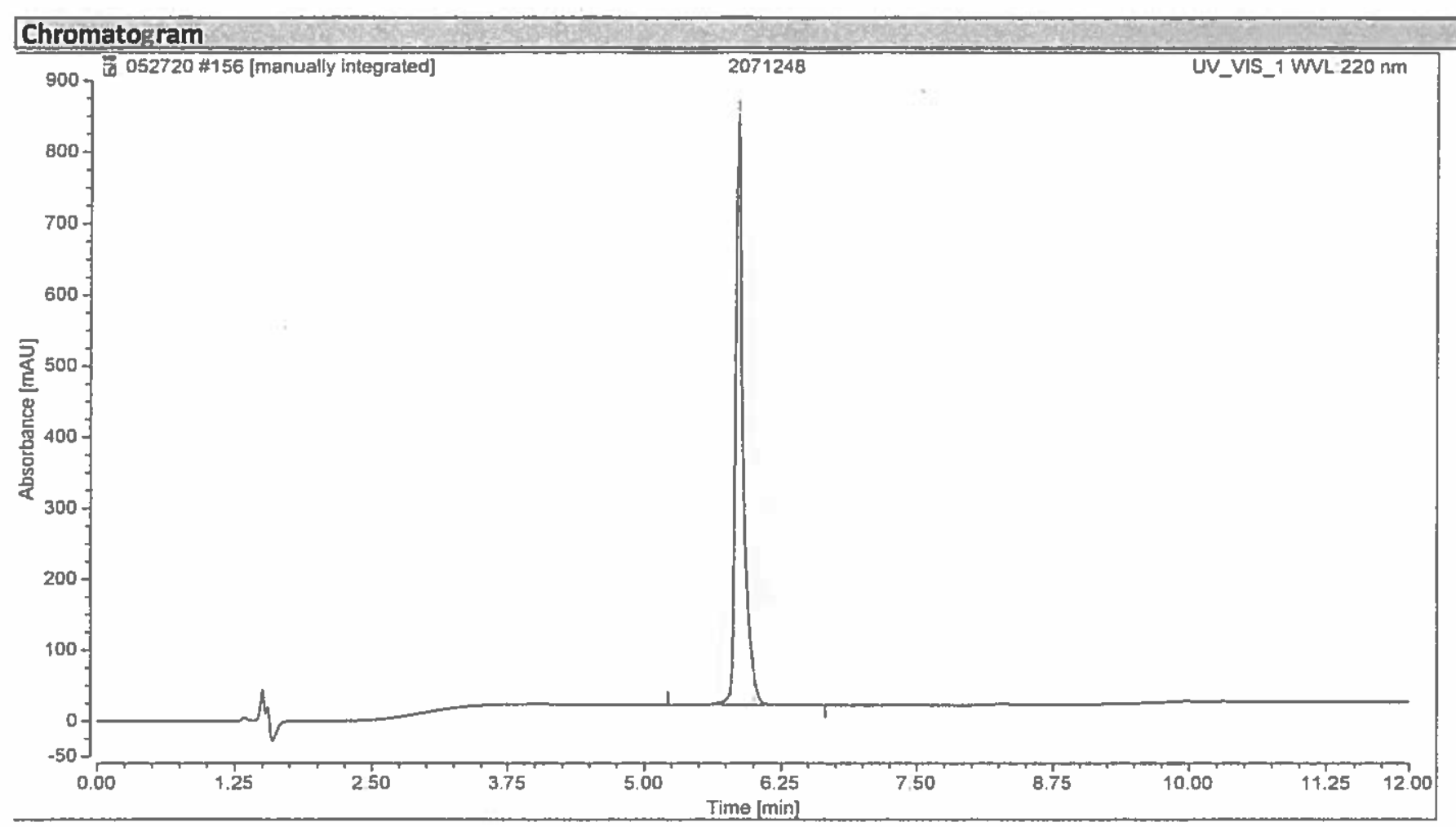

\begin{tabular}{|l|c|c|c|c|}
\hline \multicolumn{4}{|l|}{ Integration Results } & \\
\hline No. & $\begin{array}{c}\text { Retention Time } \\
\text { min }\end{array}$ & $\begin{array}{c}\text { Area } \\
\text { mAU*min }\end{array}$ & $\begin{array}{c}\text { Height } \\
\text { mAU }\end{array}$ & $\begin{array}{c}\text { Relative Area } \\
\%\end{array}$ \\
\hline 1 & 5.803 & 1.364 & 49.670 & 2.05 \\
2 & 5.853 & 63.551 & 829.478 & 95.29 \\
3 & 5.997 & 1.779 & 47.305 & 2.67 \\
\hline Total: & & 66.694 & 926.453 & 100.00 \\
\hline
\end{tabular}




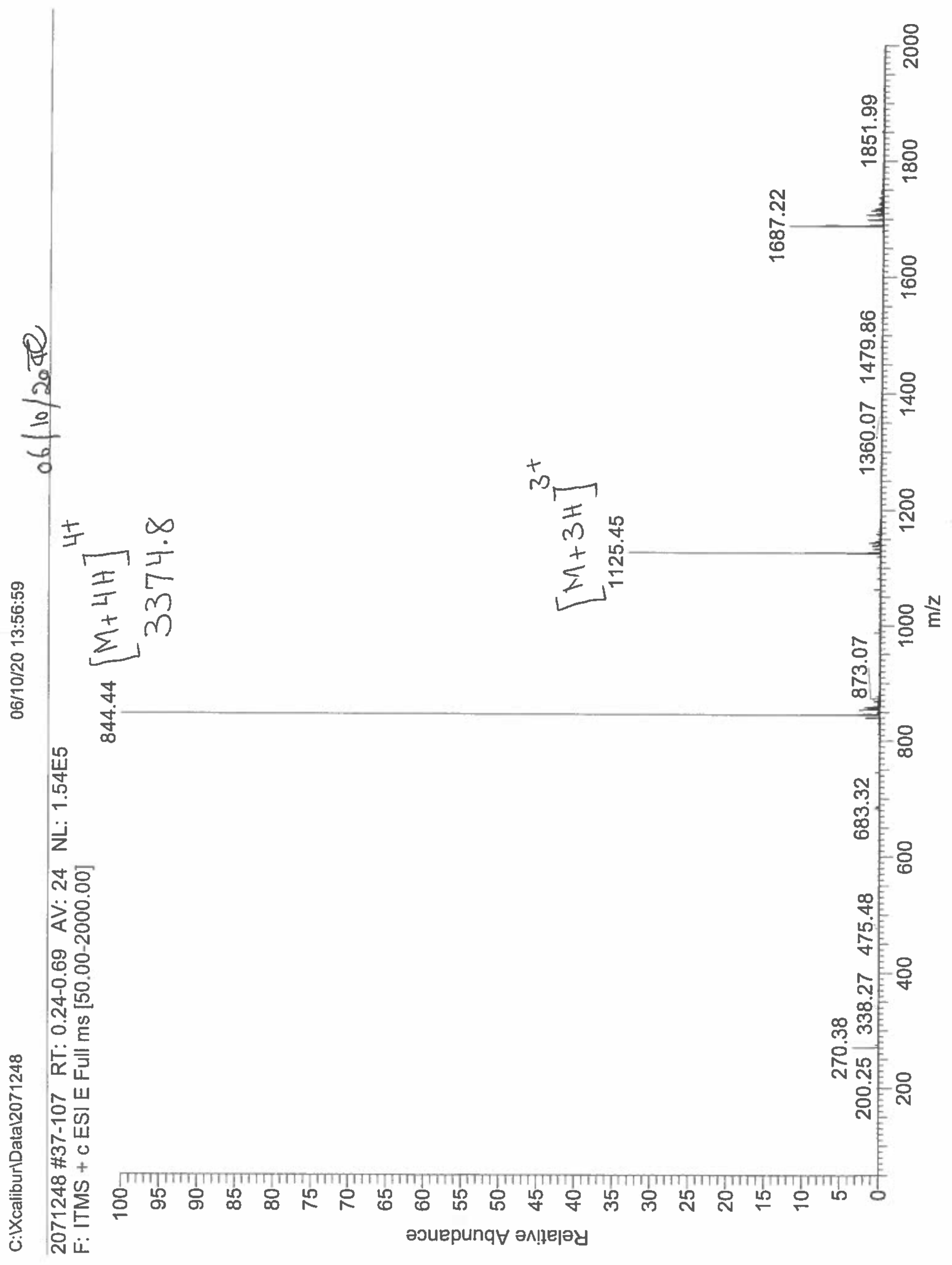




\section{¿2 Eurogentec}

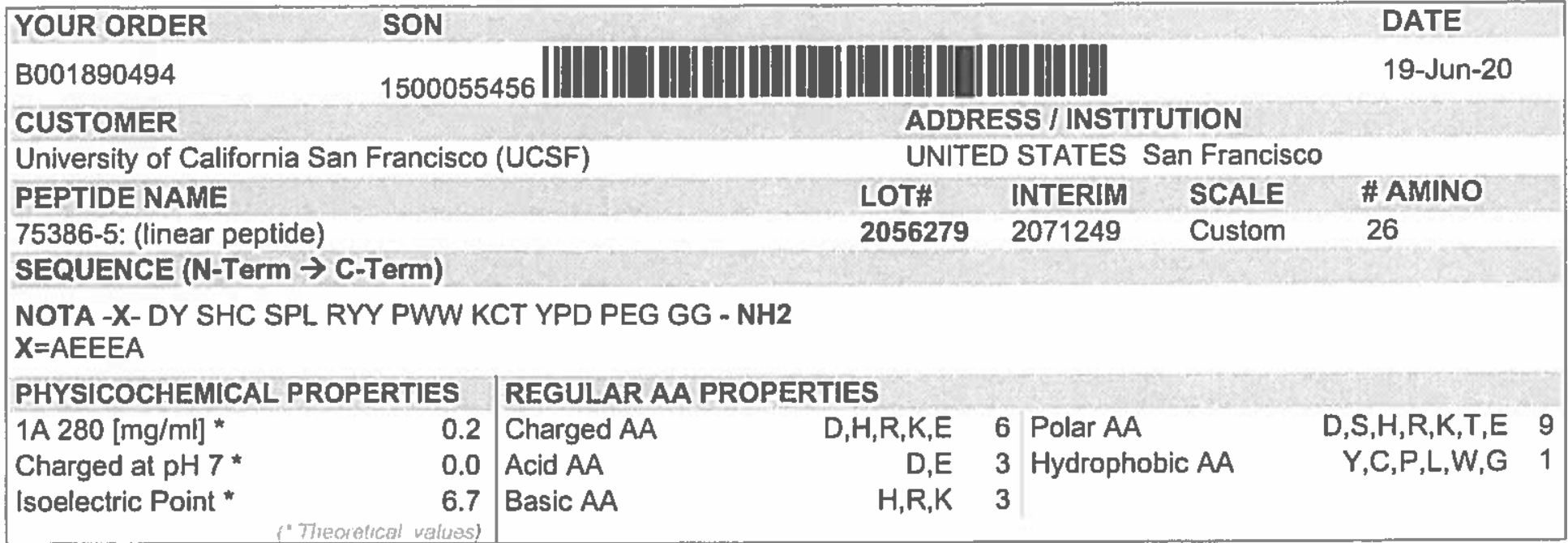

\section{QC DATA}

\section{Attribute}

Appearance

$\%$ Peak Area by HPLC

Identity

DELIVERABLE

Format

Dried

Test method
Visual
HPLC
MS

\section{Test method}

HPLC

MS

Acceptance criteria
Report result
$\geq 90 \%$
$3451.9 \pm 0.2 \%$

Result

White Powder

$95 \%$

3452.9

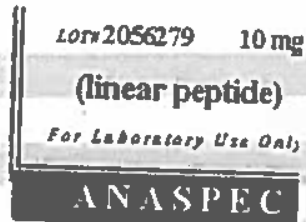

\section{DELIVERY CONDITION}

Room temperature COMMENTS

Aliquoting
Number of Aliquots 1
Qty by Aliquot (mg) $10 \mathrm{mg}$
$\begin{aligned} & \text { STORAGE CONDITION } \\ & -20^{\circ} \mathrm{C} \text {, dry }\end{aligned}$

\section{PEPTIDE RECONSTITUTION AND STORAGE}

Please read the entire section before proceeding with the solubilization of your custom peptide.

Peptides are shipped at ambient temperature as a lyophitized powder. Upon receipt store them at $-20^{\circ} \mathrm{C}$. Allow the vial to equilibrate to room temperature prior to opening.

Peptlde solublity is highly dependent on the sequence. Peptides that are more hydrophobic (high propensily of $A, F, G, V, L, I, M, W, P$ ) in nature, will require an organic solvent in order to dissolve. Peptides that are acidic in nature (high propensity of $D, E$ in the peptide sequence) require a basic aqueous bulfer to dissolve, while peptides that are basic in nature (high propensity of $\mathrm{K}, \mathrm{H}$, and $\mathrm{R}$ ) require an acidic aqueous buffer to dissolve.

To reconstitute a hydrophobic peptide, add $100 \mu \mathrm{L}$ DMSO and sonicate until a homogenous solution forms. Next, add your buffer of choice to form a $1 \mathrm{mg} / \mathrm{mL}$ solution (a higher concentration of peptide will require a greater amount of DMSO). To reconslitute basic or acidic peptides, add $1 \mathrm{~mL}$ of the appropriate buffer to the peptide and sonicate to ensure a homogenous solution forms.

Reconstituted peptides can be stored frozen at $-20^{\circ} \mathrm{C}$ for short period of time, but it is advisable to prepare multiple aliquots to avoid multiple freeze thaw cycles. We recommend that all aliquoted solutions be lyophilized if the peptide is going to be stored for extended periods of time at $-20^{\circ} \mathrm{C}$.

Addilionally, please note that peptides with a high propensity of basic residues $(R, K, H)$ in their sequence may undergo a physical change from solid powder lo an oil (via moisture absorption). This physical change does not affect the purily or functionality of the peptide.

Nomenclature used for the sequence termini:

N-lerminus: $\mathrm{H}$ means free amine ( $\left.\mathrm{NH}-\mathrm{H}_{2}\right)$, Ac mean acelyl [CH3C(O)-NH-], Pyr means pyroglutamic acid

C-terminus: $\mathrm{OH}$ means free acid $(-\mathrm{COOH}), \mathrm{NH}_{2}$ means amide [-CONH $\left.\mathrm{H}_{2}\right]$

Modifications on the side chain of amino acids are depicted in the parenthesis after the corresponding amino acid. For example; phosphorylaled serine $=\mathrm{S}\left(\mathrm{PO} \mathrm{H}_{2}\right)$ or epsiton-N-acetylated lysine $=K($ Ac)

\section{TECHNICAL SUPPORT}

If you have any questions feel free to call our Technical Support Centre

\section{EUROPE}

Q 0080066600123 (European toll free number),

$\triangle$ info@eurogentec.com

Kaneka Eurogentec S.A. Liejgo Scienç Park

Rue Bois Saint vean 5-4102 SERAING BEL GIUM

Tol: $+32(0) 43727400-\mathrm{Fax}+32(0) 42640788$

Email: info@eufogentec.5om_Web wmw.eurogentec.com

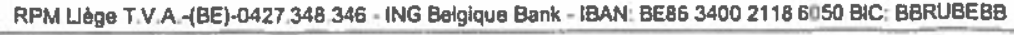

\section{NORTH AMERICA}

Q) $+1800452-5530$ (American toll free number),

$ه$ service@anaspec.com

AraSpec, Inc, 34801 Campus Drive

Fremont, CA 94555 - USA

Tel: +1 (510) 7919560 - Fax: +1 510 (791) 9572

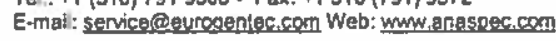




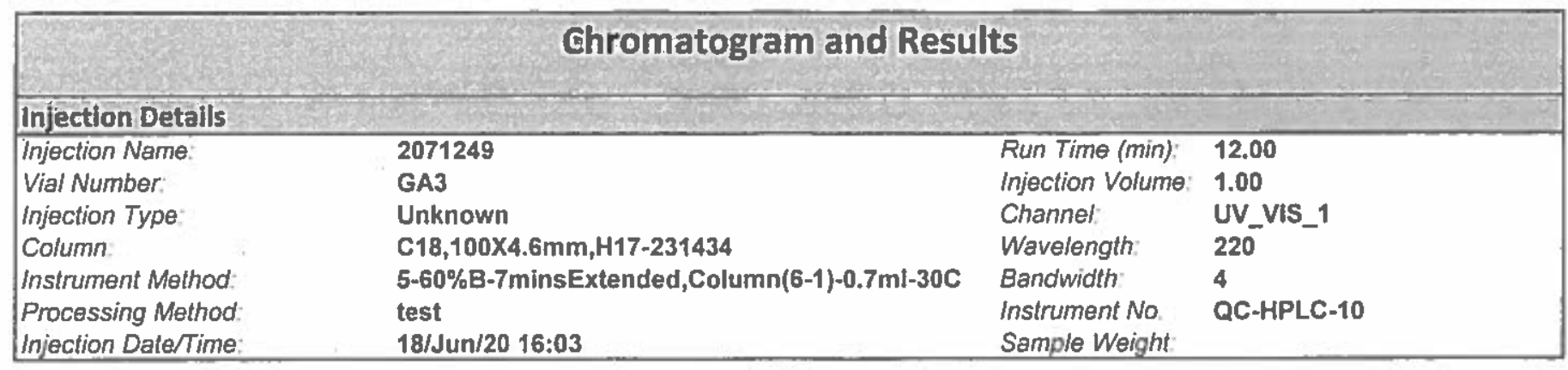

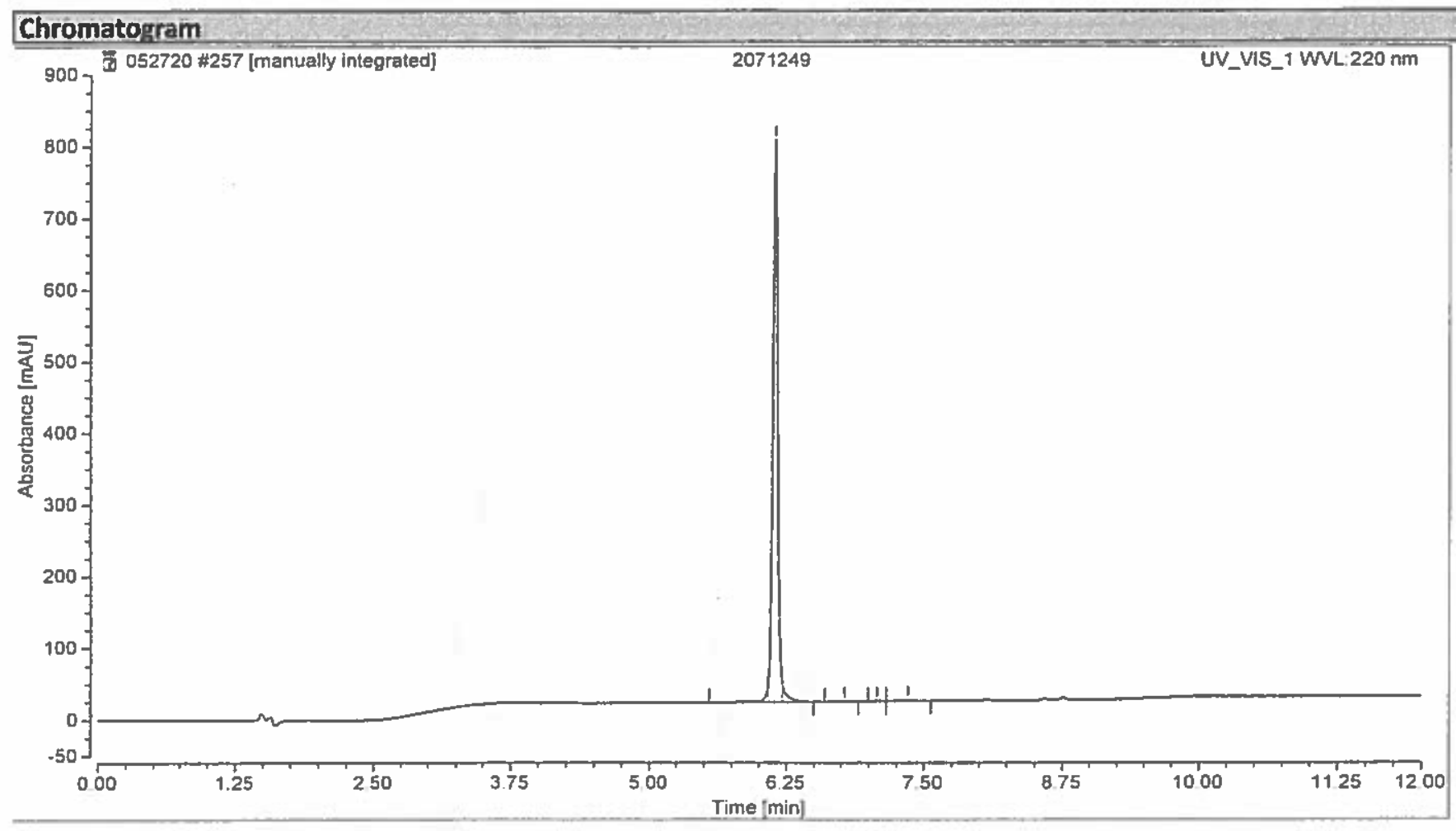

\begin{tabular}{|l|c|c|c|c|}
\hline \multicolumn{2}{|l|}{ Integration Results } & \multicolumn{3}{c|}{} \\
\hline No. & $\begin{array}{c}\text { Retention Time } \\
\text { min }\end{array}$ & $\begin{array}{c}\text { Area } \\
\text { mAU*min }\end{array}$ & $\begin{array}{c}\text { Height } \\
\text { mAU }\end{array}$ & $\begin{array}{c}\text { Relative Area } \\
\%\end{array}$ \\
\hline 1 & 6.083 & 0.670 & 19.269 & 1.55 \\
2 & 6.147 & 41.100 & 784.336 & 9532 \\
3 & 6.217 & 1.101 & 25.057 & 2.55 \\
4 & 6.783 & 0.024 & 0.553 & 0.06 \\
5 & 7.073 & 0.036 & 0.654 & 0.08 \\
6 & 7.360 & 0.186 & 1.409 & 0.43 \\
\hline Total: & & 43.117 & 831.279 & 100.00 \\
\hline
\end{tabular}




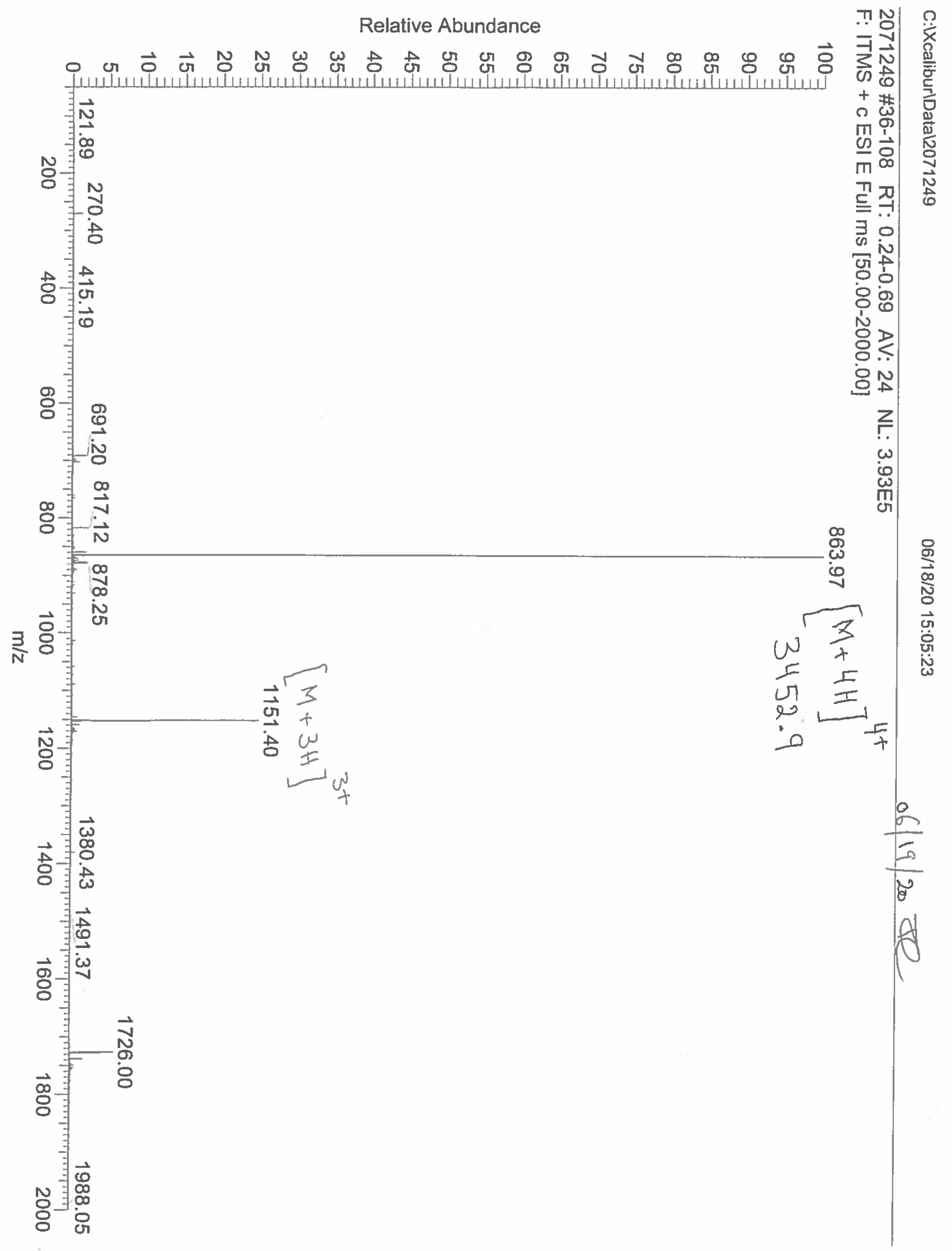


Eurogentec

ANASPEC PEPTIDE QC Data Sheet

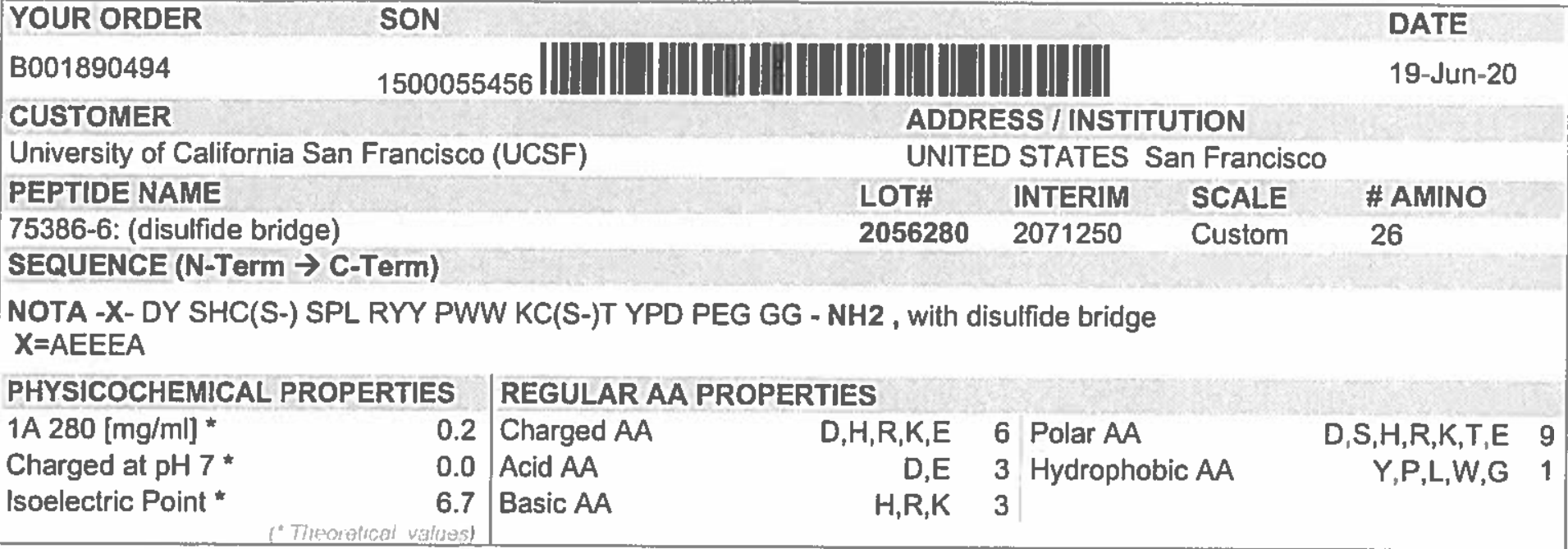

QC DATA

Attribute

Appearance

$\%$ Peak Area by HPLC

Identity

DELIVERABLE

Format

Dried

\section{DELIVERY CONDITION}

Room temperature

COMMENTS

\section{Acceptance criteria \\ Report result \\ $\geq 95 \%$ \\ $3449.8 \pm 0.2 \%$}

\begin{tabular}{ll} 
Test mothod & Acceptance criteria \\
\cline { 2 - 2 } Visual & Report result \\
HPLC & $\geq 95 \%$ \\
MS & $3449.8 \pm 0.2 \%$
\end{tabular}

Aliquoting

Number of Aliquots 1

Qty by Aliquot (mg) $10 \mathrm{mg}$

STORAGE CONDITION

$-20^{\circ} \mathrm{C}, \mathrm{dry}$

\section{Result \\ White Powder \\ $95 \%$ \\ 3451,0}

\section{PEPTIDE RECONSTITUTION AND STORAGE}

Please read the entire section belore proceeding with the solubilization of your custom peptide.

Peptides are shipped at ambient temperature as a lyophilized powder. Upon receipt store them at $-20^{\circ} \mathrm{C}$. Allow the vial to equilibrate to room temperature prior to opening.

Peptide solubility is highly dependent on the sequence. Peplides that are more hydrophobic (high propensity of $A, F, G, V, L, I, M, W, P$ ) in rature, will require an organic solvent in order to dissolve. Peptides that are acidic in nature (high propensity of $D$. $E$ in the peptide sequence) require a basic aqueous buffer to dissolve, while peptides that are basic in nature (high propensity of $\mathrm{K}, \mathrm{H}$, and $\mathrm{R}$ ) require an acidic aqueous buffer lo dissolve.

To reconstilute a hydrophobic peptide, add $100 \mu \mathrm{L} \mathrm{DMSO}$ and sonicate until a homogenous solution forms. Next, add your buffer of choice to form a $1 \mathrm{mg} / \mathrm{mL}$ solution (a higher concentration of peptide will require a greater amount of DMSO). To reconstitute basic or acidic peptides, add $1 \mathrm{~mL}$ of the appropriale buffer to the peptide and sonicate to ensure a homogenous solution forms.

Reconstituled peplides can be stored frozen at $-20^{\circ} \mathrm{C}$ for short period of time, but it is advisable to prepare multiple aliquots to avoid multiple freeze thaw cycies. We recommend that all aliquoted solutions be lyophilized if the peplide is going to be stored for extended periods of time at $-20^{\circ} \mathrm{C}$.

Additionally, please note that peptides with a high propensity of basic residues $(R, K, H)$ in their sequence may undergo a physical change from solid powder to an oil (via moisture absorplion). This physical change does not affect the purity or functionality of the peptide.

Nomenclature used for the sequence fermini:

N-lerminus: $\mathrm{H}$ means free amine $\left(\mathrm{NH}_{2}-\right)$, Ac mean acetyl [CH3C(O)-NH-], Pyr means pyrogilutamic acid

C-terminus: $\mathrm{OH}$ means free acid (-COOH), $\mathrm{NH}_{2}$ means amide [-CONH ]

Modificalions on the side chain of amino acids are depicted in the parenthesis after the corresponding amino acid. For example; phosphorylated serine $=\mathrm{S}_{3}\left(\mathrm{PO}_{3} \mathrm{H}_{2}\right)$ or epsilon-N-acetylaled lysine $=K(A c)$

TECHNICAL SUPPORT

If you have any questions feel free to call our Technical Support Centre

EUROPE

(ग) 0080066600123 (European toll free number).

13 info-Qeurogentec.com

Kaneka Eurogentec S.A. LUège Science Park

Rue Bois Saint-Jean 5 - 4 to2 SERAING BELGIIM

Tel: +32(0)4 3727400 - Fax: +32(0)4 26407 B8

E-mall: infofarouroentec.com Web: whw, eurogentec.com

RPM Lidge T.V.A.-(BE)-0427.348 346 - ING Belgique Bonk - IBAN: BEB6 340021186050 BIC: BBRUBEBB

\section{NORTH AMERICA}

(b) $+1800452-5530$ (American toll free number),

service@anaspec.com

AneSpec, Inc. 34801 Campus Drive

Fremont, CA 94555 - USA

Fet: +1 (510) 7919560 - Fax: +1510 (791) 9572

E-mail: genvicegourogentec.com Web: www, anaspec.com 


\section{Chromatogram and Results}

\section{Jnjection Details}

Injection Name:

Vial Number:

Column:

Instrument Method:

Processing Method:

Injection Date/Time

\section{0}

BA2

C18, $100 \times 4.6 \mathrm{~mm}, \mathrm{H} 18-074009$

$5-60 \%-7$ mins-Bextended $-0.7 \mathrm{ml}-30 \mathrm{C}$

test

18/Jun/20 16:47
Run Time (min): 12.50

Injection Volume: 1.000

Channel: $\quad$ UV VIS_1

Wavelength: $\quad 220.0$

Bandwidih: 4

Instrument No. QC-HPLC-9

\section{Chromatogram}

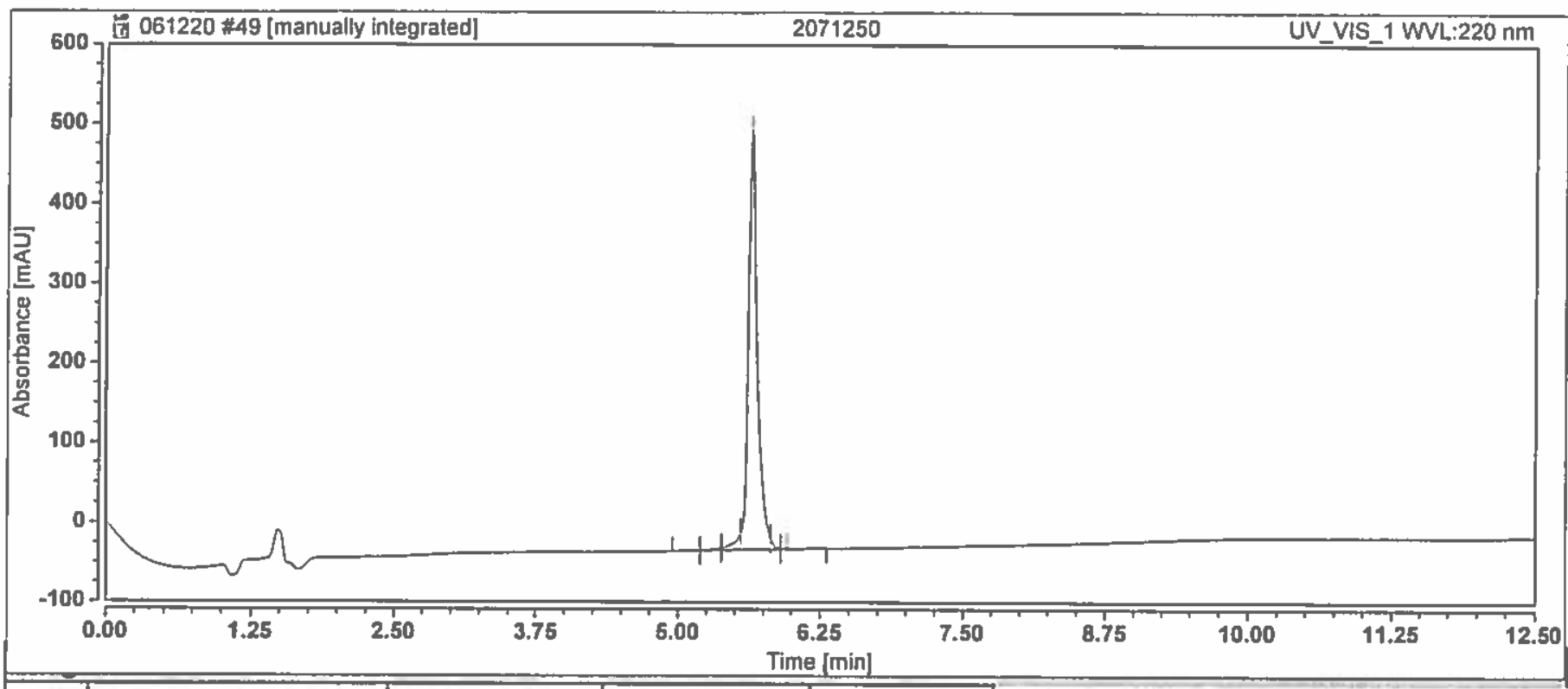

\begin{tabular}{|r|c|c|c|c|}
\hline No. & $\begin{array}{c}\text { Retention Time } \\
\text { min }\end{array}$ & $\begin{array}{c}\text { Area } \\
\text { mAU*min }\end{array}$ & $\begin{array}{c}\text { Height } \\
\text { mAU }\end{array}$ & $\begin{array}{c}\text { Relative Area } \\
\%\end{array}$ \\
\hline 1 & 5.197 & 0.014 & 0.000 & 0.03 \\
\hline 2 & 5.380 & 0.288 & 3.131 & 0.58 \\
\hline 3 & 5.553 & 1.483 & 21.673 & 2.97 \\
\hline 4 & 5.633 & 47.498 & 526.989 & 95.25 \\
\hline 5 & 5.813 & 0.411 & 13.648 & 0.82 \\
\hline 6 & 5.960 & 0.171 & 2.507 & 0.34 \\
\hline Total: & & 49.865 & 567.948 & 100.000 \\
\hline
\end{tabular}




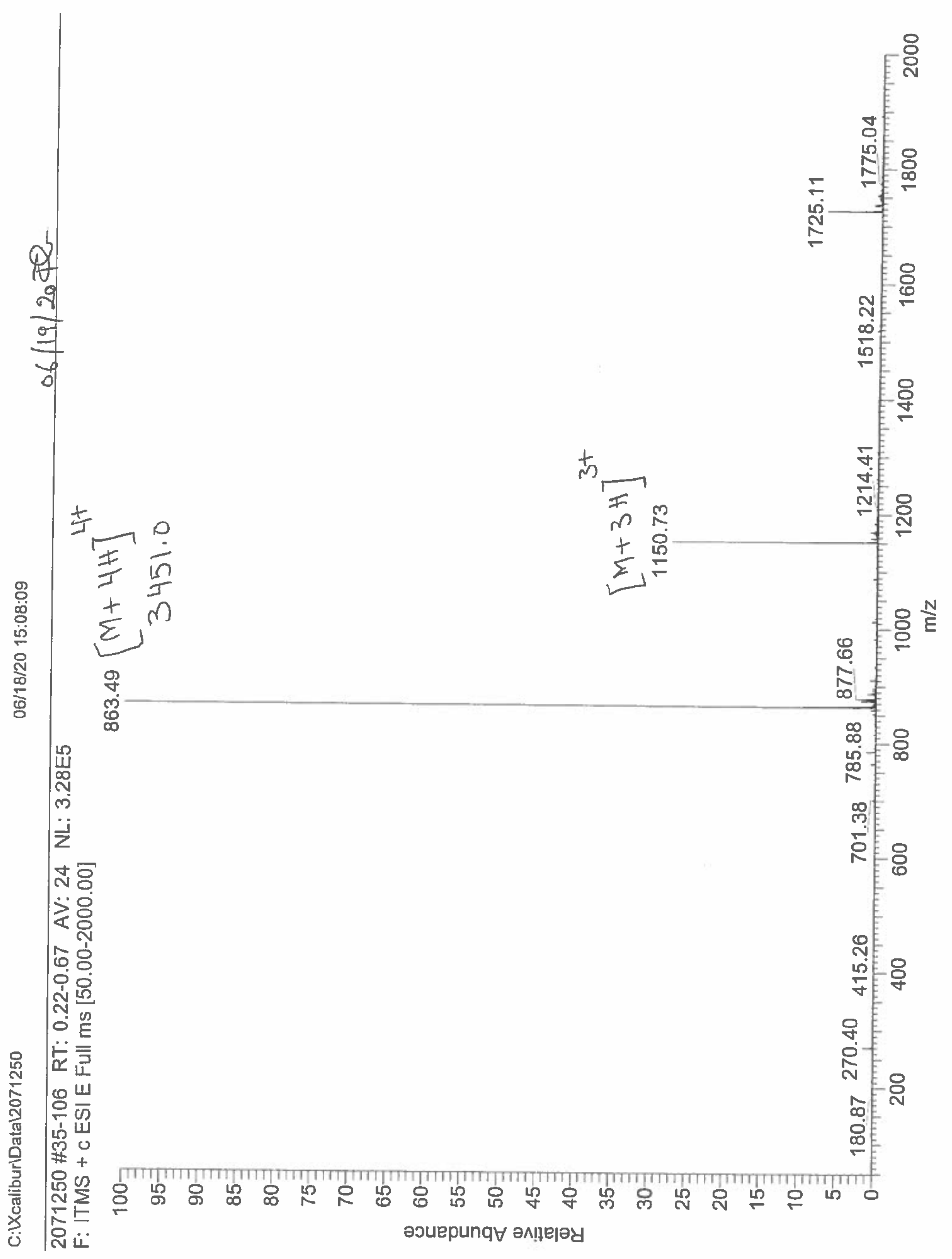

